\title{
The Multiple Roles of Hepatitis B Virus X Protein (HBx) Dysregulated MicroRNA in Hepatitis B Virus-Associated Hepatocellular Carcinoma (HBV-HCC) and Immune Pathways
}

\author{
Kurt Sartorius ${ }^{1,2,3, *}$, Leo Swadling ${ }^{4}\left(\mathbb{D}\right.$, Ping An ${ }^{5} \oplus$, Julia Makarova ${ }^{6}$, Cheryl Winkler ${ }^{5}$, \\ Anil Chuturgoon ${ }^{2}(1)$ and Anna Kramvis ${ }^{7}$ (i) \\ 1 Faculty of Commerce, Law and Management, University of the Witwatersrand, Johannesburg 2050, \\ South Africa \\ 2 Department of Public Health Medicine, School of Nursing and Public Health, University of KwaZulu-Natal, \\ Durban 4041, South Africa; chutur@ukzn.ac.za \\ 3 UKZN Gastrointestinal Cancer Research Centre, Durban 4041, South Africa \\ 4 Division of Infection and Immunity, University College London, London WC1E6BT, UK; \\ l.swadling@ucl.ac.uk \\ 5 Basic Research Laboratory, Centre for Cancer Research, National Cancer Institute, \\ Leidos Biomedical Research, Inc. Frederick Nat. Lab. for Cancer Research, Frederick, MD 20878, USA; \\ ping.an@nih.gov (P.A.); winklerc@mail.nih.gov (C.W.) \\ 6 National Research University Higher School of Economics, Faculty of Biology and Biotechnology, \\ 10100 Moscow, Russia; j-makarova@yandex.ru \\ 7 Hepatitis Virus Diversity Research Unit, Department of Internal Medicine, School of Clinical Medicine, \\ Faculty of Health Sciences, University of the Witwatersrand, Johannesburg 2050, South Africa; \\ Anna.Kramvis@wits.ac.za \\ * Correspondence: Kurt.Sartorius@wits.ac.za
}

Received: 15 June 2020; Accepted: 9 July 2020; Published: 10 July 2020

\begin{abstract}
Currently, the treatment of hepatitis B virus (HBV)-associated hepatocellular carcinoma (HCC) [HBV-HCC] relies on blunt tools that are unable to offer effective therapy for later stage pathogenesis. The potential of miRNA to treat HBV-HCC offer a more targeted approach to managing this lethal carcinoma; however, the complexity of miRNA as an ancillary regulator of the immune system remains poorly understood. This review examines the overlapping roles of HBx-dysregulated miRNA in HBV-HCC and immune pathways and seeks to demonstrate that specific miRNA response in immune cells is not independent of their expression in hepatocytes. This interplay between the two pathways may provide us with the possibility of using candidate miRNA to manipulate this interaction as a potential therapeutic option.
\end{abstract}

Keywords: hepatitis B virus; HBx protein; dysregulated; microRNA; hepatocellular carcinoma

\section{Background}

Hepatitis B virus (HBV) infection is linked with more than $60 \%$ of all hepatocellular carcinomas (HCC) in developing countries, compared with 40\% in developed countries [1], and HBV has been dubbed "the second most dangerous carcinogen after tobacco" [2,3]. Thus, HBV-associated HCC (HBV-HCC) is a leading cancer in the developing world, especially so in Africa and Asia [4]. This variant of liver carcinoma triggers a range of immune response failures that includes the dysregulation of microRNA (miRNA) [5]. miRNA provide an additional 'layer' of control in the immune system [6] by exerting a mild homeostatic effect on protein transcription and translation by way of suppressing 
complementary mRNA sequences. miRNA "see" their target by matching their nucleotide sequence to the $3^{\prime}$ untranslated region (UTR) of its target mRNA, whereas immune cells use selective cell surface receptors to bind with target antigens. In effect, multiple miRNA are activated in the presence of disease to collectively inhibit the mRNA expression of targeted genes in order modulate their expression. The ancillary role of miRNA, which can be described as mild suppressors acting in support of the immune system, helps to maintain homeostasis of the dynamic systems within which they operate [7].

Hepatitis B X protein ( $\mathrm{HBx}$ )-induced dysregulation of host miRNA in the various HBV-HCC pathways [8] can contribute to the ability of HBV to evade and control the host immune system for its own purposes of replication. This modulation can result in miRNA losing their role as part of an ancillary immune system because they are commandeered to modulate host and viral expression in favor of the virus [9]. The principal purpose of this exploratory review is to illustrate the complex role of some key miRNA that are dysregulated by the HBx protein in the HBV-HCC continuum, as well as in both the innate and adaptive immune cells. In this regard, our focus is to demonstrate how the HBx protein can dysregulate miRNA in hepatocytes in HBV-HCC pathogenesis and how this can simultaneously trigger changes in the same miRNA expression in innate and adaptive immune cell pathways. This is the connection we seek to make, namely, that in HBV-HCC pathogenesis the miRNA response in immune cells is not independent of their expression in hepatocytes. We, therefore, hypothesize that in HBV-HCC pathogenesis specific HBx-dysregulated miRNA in hepatocytes also become dysregulated in immune cells because of the influence of viral infection. This review provides a platform for multiple hypotheses for future studies.

\section{MicroRNA Expression and HBV-HCC Pathogenesis}

HBV infection manifests in a range of clinical conditions including the asymptomatic carrier state, inflammation, acute or fulminant hepatitis, chronic hepatitis, and the onset of cirrhosis. Acute HBV infection only persists in 5\% of adults, unlike in children where $90 \%$ of the cases do not resolve $[10,11]$. Moreover, if an individual develops chronic hepatitis B infection (CHB), the risk of progressing to $\mathrm{HCC}$ increases 100-fold if a patient is both HBsAg and HBeAg positive [12]. As viral load increases, the host immune response, triggered by viral antigens, elicits HBV-specific T-cell responses in the presence of a secondary inflammatory response, as well as increases in free radicals, interferon, tumor necrosis factor (TNF) and hepatic injury [12]. In parallel with these changes, the continuous destruction of organized extracellular matrix (ECM) and well differentiated hepatocytes results in their eventual depletion and their replacement with liver stem cells and less well organized fibrotic tissue [10]. Moreover, the integration of HBV DNA into the hepatocyte genome can trigger the oncogenic disruption of cellular genes [13] that direct apoptosis, regeneration and early senescence [14]. Oncogenic disruption leads to genomic instability that can include aberrant epigenetic change, DNA deletions, fusion transcripts cis/trans-activation, and translocations [5].

In addition to its structural proteins, $\mathrm{HBcAg}$ and $\mathrm{HBsAg}$ that form the capsid and envelope, respectively and the polymerase enzyme, $\mathrm{HBV}$ encodes for two non-particulate proteins, $\mathrm{HBeAg}$ and HBx that do not form part of the virion. The $17 \mathrm{kDa} H B x$, coded by the smallest open reading frame, $X$, is an accessory protein, which functions as a transcriptional transactivator, influencing both viral and host gene expression. Several hepatocyte signaling cascades and factors that regulate calcium, apoptosis, proliferation and the immune response can be modulated by HBx [15-18]. Unlike mammalian hepadnaviruses, the avian hepadnaviruses do not express the HBx [19]. Thus, it has been postulated that HBx may be oncogenic because hepadnavirus-associated HCC is specific to mammalian hepadnaviruses, while avian hepadnaviruses can cause chronic infection that does not progress to HCC $[20,21]$.

The HBx protein plays an important role in the pathogenesis of viral induced HCC. This multifunctional $17 \mathrm{kDa}$ protein can modulate several cellular processes directly or indirectly as a result of its interaction with the host genome. HBx integration in the host genome can influence several cellular processes including oxidative stress, cell cycle controls, apoptosis, DNA repair, as 
well as signal transduction, transcription and protein degradation [22,23]. HBx can also regulate the epigenetic machinery to influence access to miRNA transcription sites or influence intracellular processing by inhibiting miRNA processing steps like DROSHA/DICER machinery. The HBx protein can interact with transcription factors such as p53, nuclear factor-kappa B (NF-kB), and C-MYC, subsequently regulating miRNA expression. miRNA expression can also be modulated by HBV mRNA, which act as "sponges" to reduce expression [24].

As HBV-HCC progression proceeds from asymptomatic or acute HBV infection leading to HCC, multiple miRNA become increasingly permanently dysregulated as a result of HBV infection, inflammation [25], fibrosis [26], cirrhosis [14] and the onset of HCC [27]. The increasing level of miRNA dysregulation in the HBV-HCC continuum has been hypothesized to be a result of increased liver damage [28]. For example, one study showed 79 dysregulated miRNA in asymptomatic HBV carriers (ASC) versus 203 in CHB cases [29], while another study demonstrated an increase from 37 miRNA deregulated in healthy controls (HC) to 77 in ASCs, 101 in CHB and 135 in acute liver failure (ALF) [30].

\section{Immune Response in HBV and the HBV-HCC Tumor Microenvironment}

A few million years of 'warfare' between viruses and their hosts have led to the evolution of 'clever' viruses [31]. The first line of defense occurs in the innate immune system when interferon (IFN) molecules are produced and secreted from infected cells, in order to trigger anti-viral gene transcription and a broadly antiviral state [32]. HBV infection is characterized by a relatively delayed early innate immune response with weak induction of antiviral IFNs, as a result of poor detection of HBV and/or specific immunosuppression by viral proteins [33,34]. Consistent with findings in chimpanzees [35], HBV has been shown neither to induce nor interfere with the innate immune response in an ex vivo biopsy culture system [33] The subsequent induction of the adaptive immune system also appears delayed relative to other viral infections [31,36,37]. It is also notable that the persistent production of pro-inflammatory cytokines like IL-1 $\beta$ and TNF- $\alpha$ can also directly inhibit HBV replication [38]. Resolution of HBV infection is ultimately associated with the development of HBV-specific antibody producing B-cells and HBV-specific T-cells [39]. CD4+ and CD8+ T cell responses, especially CD4+ helper T-cells with a type 1 cytokine production, are thought to play important roles in controlling HBV infection, with CD8+ T cells capable of both suppressing viral replication and inducing lysis of infected hepatocytes [40]. Although $\mathrm{T}$ cell responses are induced in acute hepatitis (AH), they are significantly exhausted by their persistent exposure to HBV antigen and together with the tolerogenic environment of the liver can lead to $\mathrm{CHB}$. Moreover, patients that progress to $\mathrm{CHB}$ demonstrate a weak or undetectable virus specific T-cell response and no detectable HBV surface antigen-specific antibody response. Viral persistence could also result from viral modulation of antigen presentation in the liver [41-43], for instance by suppressing pro-inflammatory cytokines [44], inducing immunosuppression that limits maturation and effective presentation of antigens by antigen presenting cells (APCs), or by presentation on non-professional or tolerizing APCs [45]. Numerous studies demonstrate that HBV also has the ability to modulate immune responses by its ability to modulate the function of dendritic cells (DCs), NK cells, T regulatory cells (Tregs) and the signaling pathways of the IFN response [40].

In $\mathrm{CHB}$ infection, inflammation, the development of fibrotic tissue and HBV DNA integration in the host genome, tumorigenesis can be spontaneous, or can develop over time with several characteristic changes in hepatocyte gene expression. Typically, these persistent conditions can lead to T-cell exhaustion, hyposensitivity and senescence as malignant tumors change the microenvironment [46]. The tumor microenvironment is markedly heterogeneous and comprises of various cell types including cancer-associated fibroblasts (CAFs), endothelial cells, pericytes, and immune cells. These immune cells include various types of lymphocytes, Tregs, tumor-associated macrophages (TAMs) and myeloid derived suppressor cells (MDSCs), as well as local and bone marrow-derived stromal stem and progenitor cells interspersed with surrounding ECM [47]. 


\section{The Regulatory Role of miRNA in the Cancer Microenvironment}

A wide range of pathological conditions in cancer are able to dysregulate miRNA modulation including the altered expression of oncogenes and tumor-suppressor genes due to chromosomal deletion or amplification, mutation and epigenetic silencing. In addition, miRNA biosynthesis can be dysregulated at multiple stages from pri-miRNA transcripts in the nucleus to mature miRNA in the cytoplasm [48]. In solid tumors, dysregulated miRNA in the tumor microenvironment can affect miRNA expression in adjacent tissue to promote carcinogenesis [49]. These mechanisms include the promotion of inflammation, angiogenesis, ECM remodeling, and immunosuppression in the neighboring tumor microenvironment [47].

Multiple miRNA in cancer cells modulate angiogenesis in the neighboring environment. For example, miR-9/-126/-135b can promote angiogenesis by indirectly amplifying the expression of VEGF-A, MERTK, IL-17 and IL-6 in the tumor microenvironment [47,50-52]. In this environment, miRNA are able to reprogram normal fibroblasts into CAFs [53] that are capable of promoting ECM production and increasing the secretion of cytokines and chemokines that promote tumorigenesis [54]. ECM remodeling and epithelial mesenchymal transition (EMT), are common features of carcinogenesis that are modulated by miRNA that promote this transition via the recruitment of endothelial cells to induce angiogenesis and collagen remodeling. Downregulated miR-29b, for instance, fails to modulate VEGF-A resulting in the promotion of MMP9 driven ECM remodeling [50,51,55].

\section{HBx-dysregulated miRNA Targets in HBV-HCC and Immune Pathways}

In the HBV-HCC tumor micro-environment, a range of HBx-dysregulated miRNA in hepatocytes modulate pathogenesis. Simultaneously, innate and adaptive immune cells respond to the presence of the tumor micro-environment. This response across different cell types occurs via the recognition of viral nucleic acids, viral proteins or tissue-damage and results in the activation of different families of cellular receptors [32]. This section demonstrates that the same miRNA can be dysregulated in hepatocytes in HBV-HCC pathogenesis, as well as in immune cells for a range of related reasons, e.g., to modulate pro and anti-inflammatory response [56]. This is the connection we seek to make, namely, that the miRNA response in immune cells is not independent of HBV-HCC pathogenesis in hepatocytes.

The HBx protein dysregulates multiple miRNA in HBV-HCC and these same miRNA modulate genes that potentially control innate and adaptive immune pathways in HBV-HCC (Table 1). The literature proposes four principal HCC pathways that become increasingly dysregulated as carcinogenesis progresses. These include the Retinoblastoma-Tumor Protein 53 (RB1-TP53) suppressor networks, the Phosphoinositide 3-kinase/mitogen-activated protein kinase (PI3K/MAPK) pathway, the Wingless related integration site/beta-Catenin (WNT/ $\beta$-Catenin) pathway and the Janus kinase/signal transducer (JAK/STAT) pathway [57,58].

In HBV-HCC, HBx downregulated miRNA and their gene targets are illustrated in Table 1 and HBx-upregulated miRNA in Table 2. The verified gene targets in hepatocytes in HBV-HCC are listed in column 1 . The verified immune gene targets of the same miRNA are separately and correspondingly shown in the second column. The immune gene targets are not all specifically identified in HBV-HCC studies and different studies include other cancer types. This second column also includes immune gene targets in both hepatocytes and leukocytes. Typically, downregulated miRNA (Table 1) fail to modulate oncogenic proteins. For example, the HBx downregulated Let-7 family members in HBV-HCC fail to modulate multiple oncogene targets like RAS/MYC/SMAD4 and WNT1. 
Table 1. HBx-downregulated miRNA targets in HBV-HCC and immune pathways.

\begin{tabular}{|c|c|c|c|}
\hline $\operatorname{miR}$ & $\begin{array}{c}\text { HBV-HCC Target } \\
\text { (Hepatocytes) }\end{array}$ & $\begin{array}{c}\text { Immune Target } \\
\text { (Hepatocytes/Leukocytes) }\end{array}$ & Reference \\
\hline let-7/miR-98 & $\begin{array}{l}\text { STAT3/RAS/HMGA2/MYC/ } \\
\text { IL-6/IL-10/TLR-4/COL1A2/NGF/BCL-XL/BCL-2/MCL-1 }\end{array}$ & $\begin{array}{c}\text { MYC/STAT3/IFN-b/ } \\
\text { RAS/TLR4/BCL-XL/SMAD2/SMAD4/APC2/WNT1/HMGA2/PLZF/ } \\
\text { IFN } \gamma / \text { IL-4/IL-17/LIN28B/IGF2BP1/NF2 }\end{array}$ & [59-72] \\
\hline miR-1 & EDN1/PI3K/AKT/HDAC4/MET & HDAC4/E2F5/HSP60/HSP70/KCNJ2/GJA1 & [73-76] \\
\hline miR-101 & GSTP1/FOS/EZH2/MCL-1/DNMT3A/RASSF1/PRDM2 & ICOS (naïve T-cells)/MCL-1 & {$[9,77-82]$} \\
\hline miR-101-3p & ND, RAP1B/MCL-1,SOX9 & ICOS/MCL-1 & {$[83,84]$} \\
\hline $\mathrm{miR}-122$ & CTNNB1 & SOCS3/IFN/IP-10/BCL-W & {$[24,85-88]$} \\
\hline & CCNG1 modulated p53/GLD2 & & [89-92] \\
\hline & NDRG3/GALNT10/CCNG1/PTTG1 & & [93-96] \\
\hline & PBF/ADAM10/CCNG1/Igf1R/ADAM 17/BCL-W/NDRG3 & & {$[24,89,96-99]$} \\
\hline miR-124 & STAT3 and PIK3CA & STAT3/TRAF6/CYCLIND3/BM11 & [100-103] \\
\hline miR-125b & SMAD2/4/Sirtuin7/SUV39H1/ & PRDM1/IRF4/TNF $\alpha / B C L-2 / M C L-1 / L I N 28 /$ RFF4/KLF13/BMF/BCL-2/SMAD2/ & {$[24,67-69,104-112]$} \\
\hline miR-132 & AKT & p300/IRAK4/FOXO3/SOX4/ & [113-117] \\
\hline miR-136 & AEG-1 & RIG-1/NF-kB & [118-120] \\
\hline miR-138 & $\mathrm{CCND} 3 / \mathrm{CDK} 4 / 6$ & CTLA-4/PD-1/PD-L1 & [121-123] \\
\hline miR-139-5p & ZEB $1 / 2$ & $\mathrm{IL}-4 / \mathrm{IFN}-\gamma$ & {$[24,124-126]$} \\
\hline miR-145 & MAP3K/CUL5/HDAC2/ADAM17 & IFN-b/TIRAP/TRAF6 & {$[63,127-130]$} \\
\hline miR-148a & $\begin{array}{l}\text { HPIP/AKT/ERK/FOXO4/ATF5/ } \\
\text { MTOR/MET/ACVR1 }\end{array}$ & CaMKII $\alpha /$ KIT/MET/SIPI/BACH/PTEN/BIM/GADD45/ & [24,131-138] \\
\hline miR-152 & DNMT1/GSTP/CDH1/KIT & CaMKII $\alpha /$ KIT & {$[134,135,139-141]$} \\
\hline $\mathrm{miR}-15 \mathrm{a} / 16$ & $\mathrm{CCND} 1 / \mathrm{BCL}-2 / \mathrm{CDK} 4 / 6$ & BCL-2/ARE/CCND1NGN3 & {$[24,142-147]$} \\
\hline miR-15b & FUT2/GloboH/HNF $\alpha$ & ARE & {$[146,148,149]$} \\
\hline mIR-16 & Cyclin D1, NCOR2 & $\mathrm{ARE} / \mathrm{TNF} \alpha$ & {$[24,142,146,150]$} \\
\hline miR-18a & ER $\alpha /$ CTGF & PIAS3 & {$[151-153]$} \\
\hline miR-192 & IL-17/SLC39A6/SNAIL & IL-17RA & [24,154-156] \\
\hline miR-193b & ING5/CCND1/ETS1 & TGF- $\beta 2$ & [157-159] \\
\hline miR-200 & ZEB $1 / 2$ & & {$[24,160]$} \\
\hline miR-205 & ACSL4/E2F1/ZEB1/2 & & {$[24,161,162]$} \\
\hline $\mathrm{miR}-21$ & PTEN/PIP3/AKT/MASPIN/RECK & MYD88/IRAK1/IL-12/SMAD7/PTEN/PDCD4/TPM1 & {$[127,163-166]$} \\
\hline miR-216b & IGF2BP2/IGF2/AKT/mTOR/MAPK/ERK & JAK2 & {$[127,167,168]$} \\
\hline miR-222 & $\mathrm{p} 27$ & p27 Kip/KIT & {$[65,127,145,169]$} \\
\hline $\mathrm{miR}-23 \mathrm{a}$ & MYC/CDH1/Sprouty2 & IL-4/GATA/FAS & {$[24,170-174]$} \\
\hline $\mathrm{miR}-26 \mathrm{a} / \mathrm{c}$ & $\mathrm{IL}-6 / \mathrm{IFN} \alpha / \mathrm{ER} \alpha / \mathrm{Cyclin} \mathrm{D} 2 / \mathrm{Cyclin} \mathrm{E} 2 / \mathrm{c}-\mathrm{JUN} / \mathrm{CDK} 4 / 6$ & IFN-b CDK4/6/MALT1 & {$[63,175-178]$} \\
\hline $\mathrm{miR}-29 \mathrm{c}$ & BCL-2/MCL-1/TNFA1P3 & TCL-1/MCL-1/IFN- $\gamma$ & [179-183] \\
\hline miR-338-3p & CCND1 & ICAM-1 & {$[184-186]$} \\
\hline miR-34a & $\begin{array}{l}\text { CCL22/MAP4K4/SIRT1/CCND1/CDK4/6/ } \\
\text { MET/C-JUN/CDK2 }\end{array}$ & IFN-b/FOXP1/CDK2/4/6/SIRTI/CCL22/FOXPN & {$[63,65,187-193]$} \\
\hline miR-363-3p & SPI-1 & NO IDENTIFIED IMMUNE TARGET & {$[24,194]$} \\
\hline $\mathrm{miR}-373$ & CDH1 & MTOR/SIRT1/RELA & [195-198] \\
\hline miR-375 & AEG-1 & JAK2/STAT3 & [118] \\
\hline miR-429 & Rab18, NOTCH1 & SOX2/BCL-2/SP-1 & [199-202] \\
\hline $\mathrm{miR}-520 \mathrm{~b}$ & HBXIP & RELA & {$[198,203]$} \\
\hline miR-548p & HBXIP, IFN- $\lambda 1$ & IFN- $\lambda 1$ & {$[204,205]$} \\
\hline miR-661 & MTA1/NF-kB/iNOS & NO IDENTIFIED IMMUNE TARGET & [23] \\
\hline
\end{tabular}


Table 2. HBx-upregulated miRNA targets in HBV-HCC and immune pathways.

\begin{tabular}{|c|c|c|c|}
\hline $\operatorname{miR}$ & $\begin{array}{l}\text { HBV-HCC Target } \\
\text { (Hepatocytes) }\end{array}$ & $\begin{array}{c}\text { Immune Target } \\
\text { (Hepatocytes/Leucocytes) }\end{array}$ & Reference \\
\hline miR-1 & MASPIN/HDAC4/E2F5 & HDAC4//E2F5/HSP60/HSP70/KCNJ2/GJAJ & {$[74,206]$} \\
\hline $\mathrm{miR}-107$ & AXIN2/MASPIN & CDK6 6 & [206-209] \\
\hline miR-125a & ERBB2, HBsAg & TNF- $\alpha /$ BCL-2/KLF13/BMF & {$[9,108,109,140,210,211]$} \\
\hline miR-143 & FNDC3B & MAPK7 & {$[24,212,213]$} \\
\hline miR-146a & CFH/STAT1 & $\begin{array}{l}\text { IRAK1/TRAF6/IL-1/IRAK2/IL-4/IFN- } \gamma / \text { TIRAP/ } \\
\text { NF-kB/IFN } \gamma / \text { STAT1 }\end{array}$ & {$[6,9,65,126,130,145,214-223]$} \\
\hline miR-155 & PTEN/SOX6/ZHX2/SOCS1 & 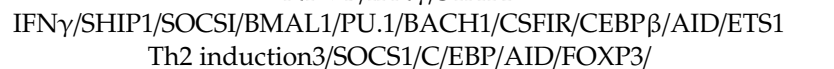 & {$[6,9,145,221,224-238]$} \\
\hline miR-17-92 family & E2F1, Cyclin G1/PTEN/p21/p27/p57 & $\begin{array}{c}\text { TNFSF9/CCL-5/IKBKE/c-MAF/AMLI/TP53INPI } \\
\text { c-MAF/IFN } \gamma / \text { CD69/PTEN/TGFBR11/p27/p21/E2F/PHLPP2/BIM/CREB1 }\end{array}$ & {$[6,9,65,145,239-245]$} \\
\hline miR-181a & FAS, E2F5 & AID/DUSP5/NLK/PTPN22/SHP2/DUSP6/CD69/BCL-2 & {$[6,244,246-251]$} \\
\hline miR-199a-5p & $\mathrm{CHC}$ & $\mathrm{CD} 19+$ & {$[9,121]$} \\
\hline miR-203a & RAP1A & SMAD1/BCL11B/RARB/PRKCA/PRKCB1/FMRP/ & [252] \\
\hline miR-21 & PDCD4, PTEN, MASPIN, RECK & PTEN/MYD88/IRAK1/PDCD4/SMAD7 & {$[65,127,164,206,253-257]$} \\
\hline miR-215 & PTPRP & NO IDENTIFIED IMMUNE TARGET & {$[154,216,258]$} \\
\hline miR-221 & ER $\alpha$, DDIT4/BMF/p27/p57/PTEN/p21/SOCS3 & PTEN/SOCS3/p57/KIT/p27 kip- & {$[65,102,145,169,259-264]$} \\
\hline miR-222 & P27 ${ }^{\mathrm{kip}-1 / \mathrm{PTEN} / \mathrm{PPP} 2 \mathrm{R} 2 \mathrm{~A} / \mathrm{p} 57 / \mathrm{p} 21}$ & $\mathrm{p} 27^{\mathrm{kip}-1} / \mathrm{PTEN} / \mathrm{KIT}$ & {$[127,145,169,261,264-267]$} \\
\hline miR-224 & PAK4/MMP9 inhibitor-5/SMAD4 & AP15/SMAD4 & [268-271] \\
\hline miR-27a & PPAR $\gamma / F O X O 1 / A P C / P 53 / R X R \alpha$ & IL-4/PPAR $\gamma$ & {$[272-275]$} \\
\hline $\mathrm{miR}-29 \mathrm{a} / \mathrm{b}$ & PTEN/PI3K/AKT/MMP-2 & $\begin{array}{l}\text { IFNARI/ IFN/T-Bet/EOMES/PTEN/MCL-1/ } \\
\text { IFN- } \gamma / \text { SLFN4/DNMT3/CDC42/HBP1/TCL1 }\end{array}$ & {$[127,145,182,183,276-278]$} \\
\hline miR-30c & HMBOX1 & PRDMI/P53 & [60,279-281] \\
\hline miR-331-3p & ING5 & E2F1/ & {$[282,283]$} \\
\hline miR-545/374a & ESRRG & AKT1 & [284-286] \\
\hline miR-602 & RASSF1a/STAT3/MYC & NO IDENTIFIED IMMUNE TARGET & {$[11,287]$} \\
\hline miR-7 & EGFR/RAF/ERK/PI3K-AKT/MASPIN/MTOR & MTOR/CD98/EGFR/TGB-1 & {$[206,285,288-292]$} \\
\hline
\end{tabular}


HBx-upregulated miRNA typically repress tumor suppressor expression in HBV-HCC pathogenesis (Table 2). For example, HBx-upregulated miR-155 represses key tumor suppressors like PTEN and SOCSI in the P13/MAPK and JAK/STAT pathways, respectively. Detailed examples of the role of six key HBx-upregulated miRNA in HBV-HCC immune pathways (miR-155/-17-92/181a/-21/-29/-34) are illustrated and discussed in Section 7 (Figures 1-4).

\section{The Regulatory Role of miRNA in Innate and Adaptive Immune Pathways}

In the absence of disease, miRNA expression constantly fluctuates in response to environmental conditions until homeostasis is restored [293]. Multiple miRNA modulate normal the innate and adaptive immune systems, first at the level of hematopoietic stem cells (HSC) and then in the differentiation and output of innate and adaptive immune cells (Tables 1 and 2). In this context, the immune environment is influenced by an elaborate network of genes whose expression is controlled by extracellular signaling, epigenetic modifiers, transcription, splicing factors, translational protein modifiers and a constellation of miRNA [294].

This section demonstrates the regulatory role of specific miRNA in specific innate and adaptive cell pathways and contrasts with Section 5 which illustrated the target genes of $\mathrm{HBx}$-dysregulated miRNA in hepatocytes in HBV-HCC pathogenesis, as well as some of their validated immune targets in both hepatocytes and immune cells.

\section{1. miRNA and the Innate Immune System}

\subsubsection{Granulocytes}

Common myeloid progenitors (CMPs) give rise to granulocyte-monocyte progenitors (GMPs). GFi1 is a transcriptional repressor protein that controls normal myelopoiesis by regulating expression of miRNA that block granulocyte-colony stimulating factor (G-CSF)-granulopoiesis (e.g., pri-miR-21/-196b) [295]. The BIC gene, which is stimulated by the immune system, transcribes miR-155, which represses SHIP1 to promote granulocyte progenitors $[231,296]$. It is hypothesized that PU.1/CEBP $\beta$ promote miR-223, which represses NF1/A to promote neutrophil differentiation while PU.1/CEBP $\beta$ upregulated miR-223 can also repress MEF2C to reduce neutrophil production [297]. In addition to miR-21, granulocyte differentiation is modulated by miR-21/-223/-21/-196b/130 [294]. miR-130, for example suppresses SMAD 4 driven TGF- $\beta 1$ signaling [298].

\subsubsection{Monocytes}

It has been demonstrated that miRNA can block the transcription factors of myeloid cell development to monocytes and their differentiation into macrophages or dendritic cells. Monocytopoiesis is stimulated via colony stimulating factor receptor (CSFR), which is promoted by the expression of Runt-related transcription factor (RUNX1); also known as acute myeloid leukemia-1 (AML-1), which in turn is repressed by miR-17-92. In a feedback loop RUNX1 also suppresses miR-17-92. In monocytopoiesis it was observed that the miR-17-92 family members are downregulated resulting in the reduced modulation of RUNX1, thus promoting CSFR expression monocyte differentiation [299]. PU.1 induced miR-424 also represses NF1/A to promote monocyte differentiation. PU.1 induced miR-223 and miR-424 targets NF1/A to promote monocyte differentiation [300].

\subsubsection{Macrophages}

In the innate immune system macrophage output is modulated by miR-155/-146a/-124/-125b/-21/-9 and Let-7e [294]. Toll-like receptor (TLR)4 signaling is increased as a result of NF- $\mathrm{kB}$ upregulation of miR-155, which in turn suppresses SOCS1/SHIP1, which then fail to modulate TLR4 [231,232]. The macrophage inflammatory response (TLR/NF- $\mathrm{KB}$ signaling) involves the upregulation of several miRNA including like miR-9/-155/-146/-147/-21 [218,232]. TLR/TNF/INF upregulation of miR-155, for instance, occurs via the activation of AP1 induced BIC transcription of this miRNA [229]. 
These upregulated miRNA are demonstrated to play a homeostatic role to both enhance and regulate inflammatory immune response and tissue damage. The upregulation of miR-21, for instance, suppresses the tumor suppressor PDCD4 expression which fails to modulate NF- $k B$ signaling [301] while upregulated miR-9 provides a countermeasure by repressing NF- $\kappa$ B expression. TLR/RIG1 upregulation of miR-146 via NF- $\mathrm{KB}$ also provides a countermeasure by repressing downstream TLR inflammation activators like IRAK1, IRAK2 and TRAF6 [302]. Upregulated miR-155 can also suppress SHIP1 and SOCSI expression to reduce their negative regulation of downstream TLR signaling, thus promoting inflammatory signaling in macrophage activation [231]. However, it has been demonstrated that AKT signaling can repress miR-155 in macrophages thus indicating a negative feedback loop to fine-tune TLR signaling [303].

\subsubsection{Dendritic Cells (DCs)}

TLR/TNF/IFN upregulated miR-155 via AP1/BIC plays a significant homeostatic role in monocytopoiesis by repressing PU.1 which activates PC-SIGN to increase pathogen cell surface uptake on DCs. Lipopolysaccharide (LPS) upregulated miR-155 modulates the TLR/Il-1 (interleukin-1) inflammation signaling pathway to regulate human monocyte-derived DCs in order to prevent excess damage [304]. DC differentiation is also modulated by miR-21/-34, which repress JAG1 and WNT1, respectively [305].

\subsubsection{NK Cells}

NK cells express the receptor natural killer group 2, member D (NKG2D), which recognizes induced-self ligands from MHC class I-like molecules from the MIC and RAET1/ULBP families that are expressed by cells as a result of viral infection or cell transformation. NK cells are able to kill an infected or abnormal cell as a result of the engagement of NKG2D with MICA/MICB on the targeted cell. The repression of MICA/MICB by miRNA is hypothesized to reduce NKG2D engagement with NK cells thus promoting cell survival $[306,307]$. Several HBsAg-induced miRNA repressed the expression of MICA and MICB via targeting their $3^{\prime}$-untranslated regions including miR-20a, miR-93, miR-106b, miR-372, miR-373 and miR-520d [308]. The output of NK cells is influenced by miRNA like miR-181a/-150 and Let-7 [294]. Upregulated miR-181a/b, for instance, play a role in upregulating NOTCH signaling to increase NK cell output by suppressing NLK, which acts as a mediator of NOTCH expression [250].

Finally, the output of megakaryocytes, erythrocytes and other innate cells (e.g., mast cell] is modulated by miRNA like miR-10a/-150/-144/-451/-221/-222/-223 [294]. miR-221/-222 suppress $\mathrm{p} 27$ to influence mast cell proliferation [264] while miR-144/-451 suppresses RAC1 and ETS2 to influence megakaryocyte erythrocyte progenitor (MEP) output and differentiation, respectively [309].

\section{2. miRNA and the Adaptive Immune System}

Lymphopoiesis is modulated at various stages by miRNA from common lymphoid progenitors (CLP) to the final output of mature $\mathrm{T}$ and $\mathrm{B}$ cells.

\subsubsection{T-Cells}

Proliferating T-cells have been shown to synthesize mRNA with shorter $3^{\prime}$ binding sites thus potentially rendering them less sensitive to miRNA induced silencing than resting T-cells [310]. DICER deficiency, for instance, has been demonstrated to influence aberrant T-cell differentiation [311]; however, two specific miRNA have been shown to play a specific role in T-cell development, namely, miR-17-92 and miR-181a. miR-17-92 members target BIM/PTEN to promote cell survival in the double negative (DN) to the double positive (DP) stage [312], while miR-181a targets DUSP5/DUSP6/SHP2/PTPN22 in the DP to single positive (SP) stage to increase TCR signaling and influences the antigen recognition sensitivity of mature T-cells [249]. In the Th1/2 differentiation stage miR-155 expression is thought to promote differentiation into Th1 cells as a result of targeting 
MAF [228,229]. This BIC encoded miRNA also represses SOCSI that, in turn, represses Treg generation to regulate autoimmune response [313,314]. miR-326 regulates Th-17 differentiation via the repression of ETS1 [315].

The activation and proliferation of T-cells is further influenced by miR-181a stimulated TCR signaling; however, a negative feedback loop represses the output of T-cells because miR-181a modulates CD69 led activation of T-cell output. CD69 is further repressed when TCR led induction of miR-17-92 family members targets this protein's expression, thus providing an additional check point for controlling T-cell output [244]. Multiple miRNA influence the differentiation and output of Th17 cells including miR-155/-21/-301/-326/206 [294]. miR-21, for instance, suppresses SMAD7 thus influencing TGF $\beta$ led signaling to promote Th17 differentiation [166], while miR-155 influences Th17 differentiation by suppressing SOCSI [238].

\subsubsection{B-Cells}

B-cell development in the bone marrow is controlled by the commitment of progenitor cells to the B-cell lineage as a result of the activation of transcription factor networks, as well as V(D)J recombination and the selection of antigen receptors [65]. In the early stages of development, the overexpression of miR-181 skewed leukopoiesis towards the development of B-cells at the expense of T-cells by repressing DUSP5, DUSP6, SHP2 and PTPN22 [316], while miR-150 can repress C-MYB to reduce Pro-B cell development $[317,318]$ and miR-17-92 absence has been demonstrated in DICER deficient Pre-B cells where this miRNA fails to repress BIM thus promoting its pro-apoptotic effect and preventing Pre-B cell development [243].

Mature B-cell differentiation is modulated by miR-155, which targets AID thus regulating GC B-cell versus Marginal zero B-cell development. This crucial miRNA also targets PU.I to block GC B-cell to plasma cell transition thereby modulating B-cell differentiation into memory cells or plasma cells. B-cells, that are miR-155-deficient, can have a defective humoral response to T-cell-dependent antigenic stimulation because of an impaired antibody class switching and differentiation into plasma cells $[228,229,319]$. In the adaptive immune system B-cell development is modulated by miR-181/-150/-212/-132/-17-92/-34a/-21/-148/-125b/146a/155 [294]. Upregulated members of the miR-17-92 family increase pro-B-cell to pre-B-cell transition by suppressing BIM [243], while p53 upregulated miR-34a has been reported to reduce pro-B-cell to pre-B-cell transition because of the suppression of the FOXP1 oncogene [193].

In the next section, we demonstrate that the same HBx-dysregulated miRNA in HBV-HCC in hepatocytes can be interdependently activated in the innate and adaptive cell pathways.

\section{HBx-Dysregulated miRNA in HBV-HCC and in Immune Pathways}

Upregulated miRNA typically reduce tumor suppressor expression in the four key HCC cancer pathways, namely, the P13K/MAPK, WNT/ $\beta$-Catenin, TP53 and JAK/STAT pathways [57]. Examples of the complexity of the interlocking roles of miRNA in HCC pathogenesis and modulation of the host immune system are illustrated in Figures 1-4. HBV infection can dysregulate multiple miRNA in order to 'cleverly' modulate the host immune response to promote its own replication and/or viral persistence. In this section, we present a few examples of HBx-dysregulated miRNA that are reported in both HBV-HCC and hematopoiesis. Many questions remain with respect to the influence of HBV infection in HBV-HCC, hematopoiesis and the role of the HBx protein. We will now review in more detail the literature on six well-characterized miRNA (miR-155, mir-17-92, miR-181a, miR-21, miR-29a/b and miR34) that are dysregulated in HBV-HCC and the diverse roles they play in lymphocyte subsets. These specific miRNA were also selected because they are all play a modulating role in highly researched cancers like those of the breast, lung and colon, as well as in HBV-HCC and in cancer-related immunology studies focusing on leukopoiesis. It is important to highlight in Figures 1-4 that the proposed miRNA immune pathways have been demonstrated in multiple cancers, including HCC, but to some extent contain a hypothetical element. This is because miRNA 
dysregulation in the immune pathways can be caused by factors in addition to $\mathrm{HBx}$, such as TLR/NF- $\mathrm{kB}$ signaling, inflammation, APCs and the expression in each of the immune pathways in the figures could be dynamic in an HBV-HCC context.

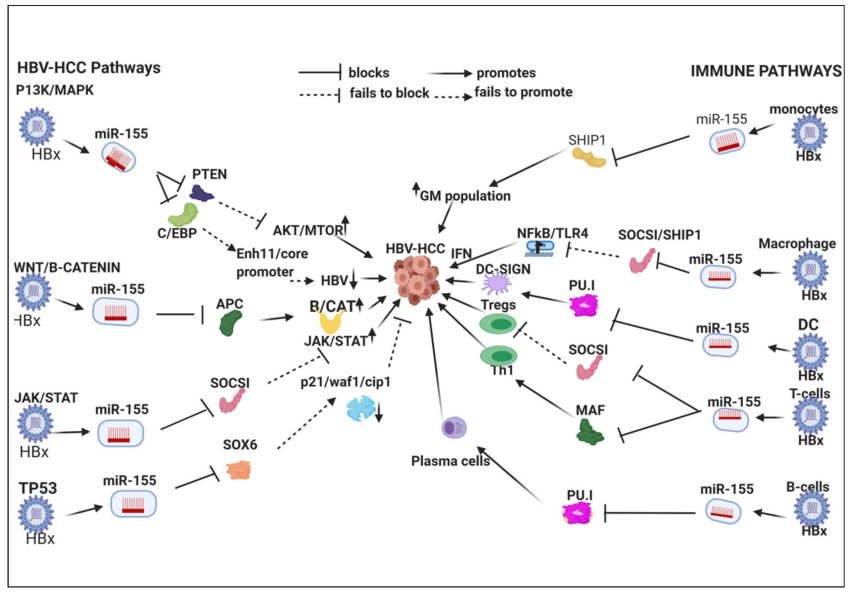

Figure 1. HBx induced MiR-155 in HBV-HCC immune pathways: This HBx-upregulated onco-miRNA promotes MTOR signaling and EMT in the P13K/MAPK pathway; it promotes $\beta$-Catenin expression to promote oncogenic proteins like C-MYC in the WNT/ $\beta$-Catenin pathway; it subdues SOCSI suppression of JAK/STAT signaling to promote oncogenic proteins like C-MYC and CCND1 in the JAK/STAT pathway and it reduces expression of tumor suppressors like p21/waf1/cip 1 to promote cell proliferation in the TP53 pathways. This upregulated miRNA, however, reduces HBV replication by repressing C/EBP promotion of ENH11/core promoter. In the immune pathway, this miRNA influences granulocyte/monocyte populations via repressing SHIP1; it represses SHIP1/SOCS1 to promote NF-kB/TLR induction of macrophages; in DCs this miRNA represses PU.1 induction of DC-SIGN to reduce pathogen cell surface uptake; in T-cell synthesis this miRNA can repress SOCS1 to promote Treg production, it can promote Th1:Th2 ratio by repressing C-MAF; in B-cells this miRNA represses PU.1 to promote GC differentiation into memory or plasma cells.

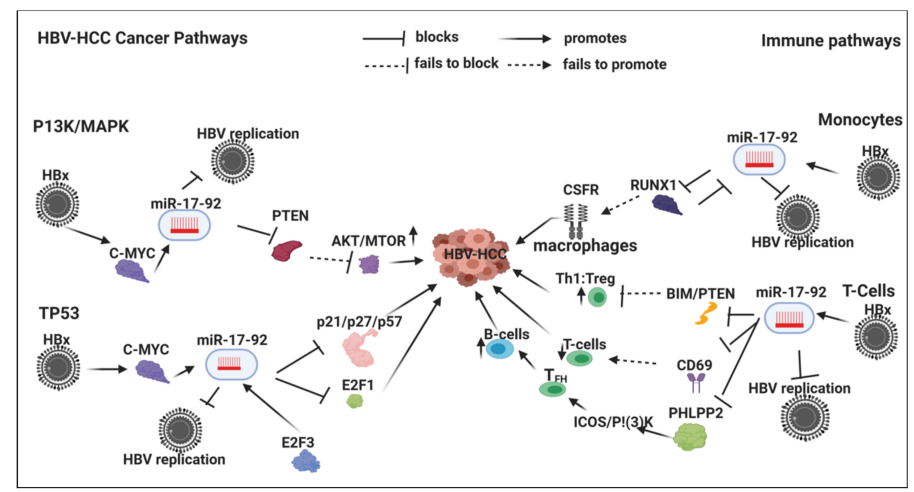

Figure 2. HBx-upregulated MiR-17-92 family in HBV-HCC immune pathways: This HBx-dysregulated miRNA family (via C-MYC) promotes HBV-HCC progression in the P13K/MAPK by repressing PTEN to upregulate MTOR signaling; in the TP53 pathways it can increase cell proliferation by repressing p21/p27/p57 and E2F1 cell cycle control primarily by promoting MTOR signaling and blocking cell cycle controls. Upregulated family can also repress HBV replication. In monopoiesis, upregulated family members can increase macrophage development via repressing RUNX1 to promote CSFR stimulation; in T-cells upregulated family members can repress PTEN/BIM to increase Th1 versus Treg expression; conversely it can repress CD69 to modulate T-cell output; B-cell output is increased when upregulated family members repress PHLPP2 to promote ICOS/P1(3)K stimulation of $\mathrm{T}_{\mathrm{FH}}$ induced B-cell response. 


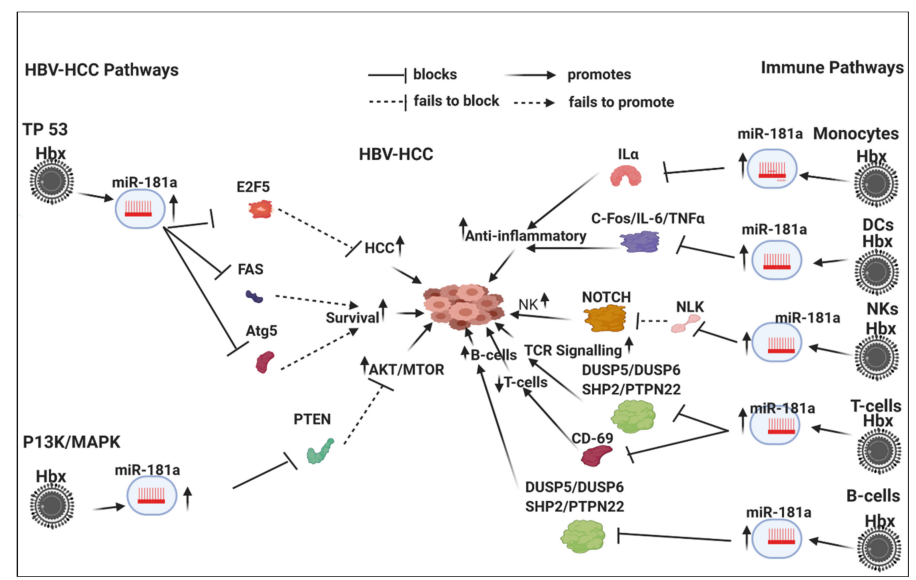

Figure 3. HBx-induced mIR-181a in HBV-HCC immune pathways: This HBx-upregulated miRNA promotes cell proliferation in the TP53 pathway by repressing cell cycle controls like E2F5 and it exerts an anti-apoptotic influence by repressing FAS/ATG5 to promote cell survival; in the P13K/MAPK this upregulated miRNA also promotes carcinogenesis by promoting MTOR signaling as a result of repressing PTEN. In the innate immune pathways, this miRNA promotes an anti-inflammotory response by repressing Il $\alpha$ and C-FOS/IL-6/TNF $\alpha$ in monocytes and DCs respectively; in NKs this miRNA upregulates NKs by repressing NLK, which then fails to repress NOTCH induced induction of NKs; in T-cells this miRNA represses DUSP5/6/SHP2/PTPN22 to increase TCR signaling induced stimulation of T-cells; however, this upregulated miRNA also represses T-cell production by reducing CD69 expression; in early stage leukopiesis this miRNA can also promote B-cell to T-cell differentiation in favor of B-cells by repressing DUSP5/6/SHP2/PTPN22.

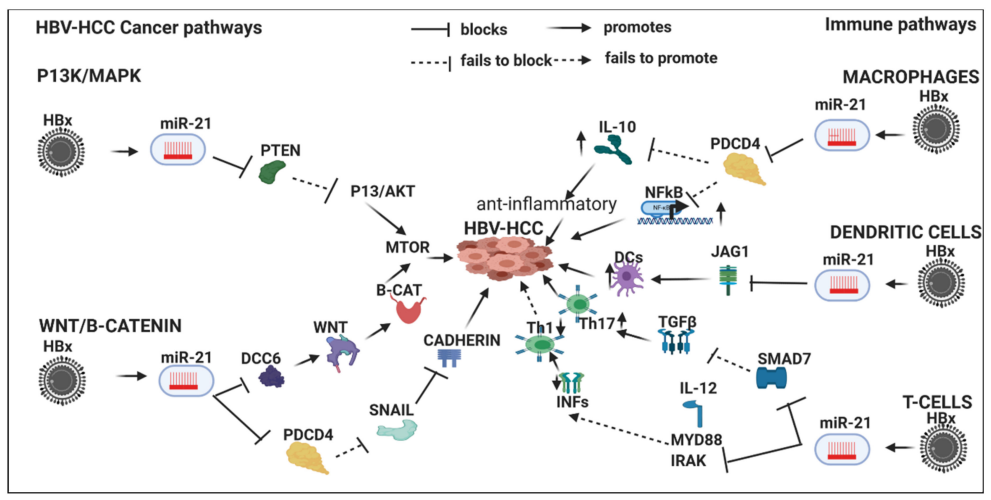

Figure 4. HBx-induced MiR-21 in HBV-HCC immune pathways: In the P13K/MAPK pathway this HBx-upregulated miRNA also promotes HCC by upregulating mTOR signaling via repressing PTEN; in the $\mathrm{WNT} / \beta$-Catenin pathway, it promotes the onco-protein $\beta$-Catenin by regulating a suppressor of WNT signaling, as well as by repressing CADHEREN via reducing PDCD4 modulation of SNAIL which acts as a repressor of CADHEREN. In macrophages, this upregulated miRNA exerts a pro and anti-inflammatory influence by repressing PDCD4. In the first case, the repression of PDCD4 reduces its own repressive of pro-inflammatory NF-KB led signaling, in the second case the repression of PDCD4 stimulates the upregulation of the anti-inflammatory IL-10; this upregulated miRNA can increase DC output by repressing JAG1; in T-cells, this miRNA can promote Th17 expression by suppressing SMAD7, which is a negative regulator of TGF $\beta$, as well as reduce Th1:Th2 ratio by targeting IL-12 induction of INFs to promote Th1.

\subsection{HBx-Dysregulated MiR-155 in HBV-HCC and in Immune Pathways}

MiR-155 is a multifunctional miRNA that plays an important ancillary regulatory role in the immune system in response to disease [320]. This miRNA is expressed in a variety of immune cell types, including B cells, T cells, macrophages, DCs, and progenitor/stem cell populations. Normally, miR-155 
is found a) ligands, and inflammatory cytokines, which rapidly increase miR-155 expression [65]. This miRNA has an important role in regulating cytokine production, inflammation, as well as in modulating myeloid and lymphoid differentiation [228]. In the immune system, miR-155 is unique in its ability to shape the transcriptome of activated myeloid and lymphoid cells [321].

As in breast, lung and colon cancer [322-324], miR-155 is frequently dysregulated in HBV-HCC pathogenesis (see Table 2). In the P13K/MAPK pathway, HBx-upregulated miR-155 represses PTEN to promote downstream AKT/MTOR signaling and epithelial to mesenchymal transition in HBV-HCC progression $[226,325]$. In the $\mathrm{WNT} / \beta$-Catenin pathway, this $\mathrm{HBx}$-dysregulated miRNA represses the APC/GSK3 destruction complex to release $\beta$-Catenin-directed transcription of oncogenic proteins like C-MYC $[24,326]$. miR-155 also plays a role in JAK/STAT pathway by repressing the SOCSI tumor suppressor to increase downstream signaling for the transcription of CCND1 and C-MYC to promote HCC cell proliferation [327,328]. In the TP53 pathway, miR-155 represses SOX6 to reduce its role in upregulating tumor suppressor expression of p21/Waf1/cip1 thus promoting reduced cell cycle controls and promoting HCC proliferation [8,224]. This HBx-upregulated miRNA also represses HBV replication by modulating CCAAT/enhancer-binding protein $(\mathrm{C} / \mathrm{EBP})$ protein that activates the Enhancer 11/basal core promoter [326].

\subsubsection{Innate Immune System}

MiR-155 modulates a range of pro- and anti-inflammatory responses in the innate immune system [56,230]. This BIC transcribed miRNA plays a major role in the modulation of NF- $\mathrm{kB}$ driven induced myelopoiesis by targeting IRAK1/TRAF6 and SHIP1/SOCS1 respectively [237,238,329]. SHIP1 is a primary target of miR-155 and its repression influences an increase in granulocyte/monocyte cell populations and a reduction in lymphocyte numbers [231,296]. It was observed that reduced levels of SHIP1 in the hematopoietic system induce myeloproliferative disorders [231]. This miRNA also targets CSFR, which may influence myeloid differentiation [65].

\subsubsection{Macrophages}

It was observed in macrophages that RNA virus infection can induce miR-155 expression via the TLR/MyD88/JNK/NF-kB dependent pathway to promote type I IFN signaling, thus suppressing viral replication, possibly to promote evasion and survival objectives. Furthermore, SOCS1, a canonical negative regulator of type I IFN signaling, is targeted by miR-155 in macrophages, and SOCS1 knockdown mediates the enhancing effect of miR-155 on type I IFN-mediated antiviral response [330,331]. TLR/TNF/IFN upregulation of miR-155, for instance, occurs via the activation of AP1 induced BIC transcription of this miRNA [229]. Upregulated miR-155 can also suppresses SHIP1 and SOCSI expression to reduce their negative regulation of downstream TLR signaling thus promoting inflammatory signaling in macrophage activation [231]. However, it has been demonstrated that AKT signaling can repress miR-155 in macrophages thus indicating a negative feedback loop to fine-tune TLR signaling [303]. The dysregulation of the SOCS-1 function as a tumor suppressor is common in HCC pathogenesis and the HBx mediated upregulation of miR-155 is a contributing factor in HBV-HCC [327,328].

\subsubsection{Dendritic Cells (DCs)}

TLR/TNF/IFN upregulated miR-155 via AP1/BIC plays a significant homeostatic role in monocytopoiesis by repressing PU.1, which activates PC-SIGN to increase pathogen cell surface uptake on DCs. LPS upregulated miR-155 modulates the TLR/IL-1 (interleukin-1) inflammation signaling pathway to regulate human monocyte-derived dendritic cells in order to ensure excess damage does not occur [304]. Decreased DC-SIGN expression in HCC is related to poor prognosis and PU.I has been identified as a metastasis suppressor possibly relating to the impairment of the antigen presenting capabilities of APCs [332]. TLRs, as well as the nuclear factor (NF)- $\kappa \mathrm{B}$, and JNK pathways are critical regulators for the production of the cytokines associated with tumor promotion. 
The cross-talk between an inflammatory cell and a neoplastic cell, which is instigated by the activation of NF- $\kappa$ B and JNKs, is critical for tumor organization [333].

\subsubsection{Adaptive Immune System}

T-Cell

MiR-155 especially modulates $\mathrm{T}$ helper cell differentiation and the germinal center reaction to produce an optimal $\mathrm{T}$ cell dependent antibody response [229]. In the Th1/2 differentiation stage miR-155 expression is thought to promote differentiation into Th1 cells as a result of targeting c-Maf $[228,229]$ and an elevated Th17 to Th1 ratio has been associated with tumor progression in HBV-HCC [334]. miR-155 in Th17 cells can also trigger autoimmune inflammation through a signaling network by targeting the Ets1/IL-23/IL-23R pathway [237].

This BIC encoded miRNA also represses SOCSI that, in turn, represses Treg generation to regulate autoimmune response [313,314]. Upregulated miR-155 enhanced Treg and Th17 cells differentiation and IL-17A production by targeting SOCS1 [238]. A meta-analysis indicated that the increased expression of Tregs has been associated with the promotion of HCC. This study also demonstrated that Treg levels in the HCC tumor microenvironment were significantly higher than in normal surrounding tissue [335]. Conversely, Fox3p directly targets miR-155 resulting in a reduction in Tregs [227]. This miRNA also modulates IFN $\gamma$ expression through a mechanism involving repression of Ship1 showing the critical roles for miRNA in the reciprocal regulation of CD4+ and CD8+ hematopoiesis [221]. miR-155 also plays a role in the generation of exhausted dysfunctional $\mathrm{T}$ cells during chronic antigen exposure. Fosl2 antagonism of miR-155 reduced could even reduce T cell exhaustion during chronic viral infection [336].

\section{B-Cell}

Mature B-cell differentiation is modulated by miR-155, which targets AID thus regulating germinal center (GC) B-cell versus marginal zone B-cell development. This crucial miRNA also targets PU.I to block GC B-cell to Plasma cell transition thereby modulating GC B-cell differentiation into memory cells or plasma cells. This miRNA, therefore, plays an important role in regulating the germinal center reaction in part by directly down-regulating AID expression [236].It has also been demonstrated that miR-155 modulates the generation of class switched B-cells by acting as a suppressor of the AID enzyme, which is essential for class switch recombination (CSR). Modulating miR-155 expression demonstrates that upregulated miR-155 will reduce generation of CSR and downregulated miR-155 will increase the net effect [6]. In B-cells with miR-155 deficiency, it has been noted that there is defective antibody class switching and differentiation into plasma cells resulting in reduced $\mathrm{T}$ cell expression that is dependent on antigenic stimulation $[228,229,319]$. Overexpression of miR-155 is linked to many cancers of B-cell origin [321].

\subsection{HBx-Dysregulated miR-17-92 Family in HBV-HCC and in Immune Pathways}

Dysregulated miR-17-92 is widely reported in lung, colorectal and breast cancer [337-339]. In HBV-HCC the HBx protein can transactivate C-MYC to upregulate miR-17-92 family members. Conversely, the miR-17-92 family members can counter regulate C-MYC expression [240]. In the P13K/MAPK pathway upregulated mIR-17-92 suppression of PTEN which then fails to modulate P13K/MTOR signaling resulting in an increase in HCC carcinogenesis [340,341]. The suppression of PTEN tumor suppressor has been widely linked to HCC [342].

In the TP53 pathways, upregulated miR-17-92 family repress E2F1 and p21/p27 and p57 cell cycle controls to upregulate cell proliferation and promote cell survival [239-241]. 


\subsubsection{Innate Immune System}

\section{Monocytes}

Monocyte production is stimulated by CSFR, which is promoted by RUNX1 expression that in turn is repressed by miR-17-92. In a feedback loop RUNX1 also suppresses miR-17-92. In monocytopoiesis it was observed that miR-17-92 family members can be downregulated resulting in the reduced modulation of RUNX1 thus promoting CSFR expression and monocyte differentiation [299]. Downregulation of RUNX1 is a feature in HCC [343], conversely the upregulation of RUNX1 has been linked to a reduction in HCC because RUNX1 suppresses VEGFA leading to reduced proliferation and migration [344]. CSFR stimulation is linked to increased macrophage activity, inflammation, tissue remodelling and HCC $[345,346]$.

\subsubsection{Adaptive Immune System}

T-Cells

The upregulated expression of miR-17-92 miRNA can repress the tumor suppressor PTEN and the pro-apoptotic protein BIM to promote lymphoproliferative disorders and autoimmunity [312]. Suppression of PTEN by miR-17-92 also promotes Th1 response versus Treg generation [245]. miR-17-92 members play a key role in T-cell development by targeting BIM/PTEN to promote cell survival in the DN to DP stage [312]. TCR led induction of miR-17-92 family members also target CD69 to control CD69 expression, which provides an additional check point for controlling T-cell output [244]. BIM and CD69 are responsible for the termination of acute inflammatory response by repressing excess T-cell production. Death following re-stimulation of the TCR, as occurs during activation-induced cell death, is known to depend on the CD95-CD95 ligand pathway [347], which is an early leucocyte activating molecule in chronic inflammation [348].

\section{B-Cells}

The absence of miR-17-92 leads to increased levels of the pro-apoptotic protein BIM and inhibits B cell development at the pro-B to pre-B transition [243]. Upregulated miR-17-92 can also suppress BIM to promote B-cell development [349]. The miR-17-92 family modulates the migration of CD4 ${ }^{+} \mathrm{T}$ cells into B cell follicles by repressing PHLPP2, which induces the co-stimulator ICOS and kinase PI(3)K promotion in T-follicular helper $\left(\mathrm{T}_{\mathrm{FH}}\right)$ cell differentiation [242].

\subsection{HBx-Dysregulated MiR-181a in HBV-HCC and in Immune Pathways}

Dysregulation of miR-181a occurs in breast, lung and colorectal cancer studies [350-352]. In the TP53 cancer pathway HBx upregulation of miR-181a contributes to increasing HCC proliferation by downregulated E2F5 expression [247], as well as facilitating HCC survival by suppressing FAS to promote an anti-apoptotic response [246]. This miRNA can also inhibit autophagy in HCC by targeting autophagy-related gene 5 (Atg5), resulting in decreased apoptosis of HCC cells and increased tumor growth [353]. In the P13k/MAPK pathway HBx-upregulated miR-181a suppresses PTEN to increase AKT/MTOR signaling that stimulates HCC progression [354]. Interestingly, miR-181a expression is also elevated by WNT/ $\beta$-Catenin signaling [355].

\subsubsection{Innate Immune System}

miR-181a has emerged as an important homeostatic agent to modulate inflammation in HBV-HCC and immune pathways.

\subsubsection{Monocytes and Macrophages}

Upregulated miR-181a regulates inflammatory responses by directly targeting the $3^{\prime}$-UTR of IL-1a and down-regulating IL-1a levels. Thus, miR-181 and IL-1a have opposite expression 
levels in monocytes and macrophages in the inflammatory state during HBV-HCC promoting an anti-inflammatory response [356].

\subsubsection{Dendritic Cells}

MiR-181a can repress the inflammatory response in DCs cells by targeting FOS. It has also been demonstrated that the expression of FOS is elevated in human hepatoma compared with adjacent tissues [357]. It is, therefore, hypothesized that this HBx-upregulated miRNA modulates an anti-inflammatory response in DCs in HBV-HCC by targeting FOS. In addition, miR-181a also modulates an anti-inflammatory response by targeting Il- 6 and TNF $\alpha$ whose elevation is noted in HCC. This miRNA, therefore, attenuates the carcinogenic properties of these two proteins in HCC [358,359]. A further role of this miRNA in DCs regulates ubiquitination targeting FOS. Interestingly, the ubiquitin C (UBC) gene has been cited for its role HCC pathogenesis [360].

\subsubsection{NK Cells}

Upregulated miR-181a plays a role in promoting NK cell output by upregulating NOTCH signaling. The upregulation of NOTCH signaling occurs because miR-181a represses NLK, which, in turn, represses NOTCH expression [250]. NOTCH signaling is activated in HCC and induces tumor formation, implying that the suppression of NOTCH signaling will attenuate HCC progression [361].

\subsubsection{Adaptive Immune System}

\section{T-Cell}

MiR-181a plays a role in the activation and proliferation of T-cells by stimulating TCR, as well as modulating both T-cell and B-cell differentiation. This miRNA augments TCR signaling by repressing TCR antagonists like DUSP5/DUSP6/SHP2/PTPN22 [249]. This miRNA plays a specific role in the development of adult T-cells by modulating the DN to DP transition by modulating PTPN22/SHP2/DUSP6. A negative feedback loop; however, modulates the output of T-cells because miR-181a also suppresses CD69 led activation of T-cell output. CD69 expression can terminate acute inflammatory response by repressing excess T-cell production [249].

\section{B-Cell}

In early stage development, the overexpression of miR-181 skewed haematopoiesis towards the development of B-cells at the expense of T-cells by repressing DUSP5, DUSP6, SHP2 and PTPN22 [316].

\subsection{HBx-Dysregulated MiR-21 in HBV-HCC and in Immune Pathways}

MiR-21 is reported as an oncogenic miRNA in lung, colorectal and breast cancer [322,362,363]. HBx-dysregulated miRNA modulates the P13K/MAPK and WNT/ $\beta$-Catenin pathways in HCC. In the P13K/MAPK upregulated miR-21 represses PTEN to reduce modulation of AKT/MTOR signaling contributing to increased HCC proliferation [354]. In the WNT/ $\beta$-Catenin pathway this upregulated miRNA promotes carcinogenesis via two sub-pathways. Firstly, it can suppress DCC6 thus preventing its modulating of WNT signaling. Secondly, this miRNA represses PDCD4, which then fails to repress SNAIL suppression of Cadherin expression which contributes to migration and increased $\beta$-Catenin expression $[253,255,256]$.

\subsubsection{Innate Immune System}

HBx-upregulated miR-21 controls a balance of pro and anti-inflammatory immune responses and elevated miR-21 levels are a marker of immune cell activation [165]. 


\subsubsection{Macrophages}

The upregulation of miR-21 promotes a pro-inflammatory response in macrophages by repressing the tumor suppressor PDCD4 expression which then fails to modulate NF- $\mathrm{KB}$ signaling [301]. Conversely, the miR-21 downregulation of PDCD4 reduces its repression of IL-10, thus promoting an anti-inflammatory response [301]. It has been proposed that the poor immune response in tumor activated macrophages may be explained by increased levels of IL-10 [165,301].

\subsubsection{Dendritic Cells}

MiR-21 modulates monocyte-derived dendritic cell (MDDC) differentiation by repressing JAG1 and WNT1 [305].

\subsubsection{Adaptive Immune System}

T-Cells

HBx-upregulated miR-21 can promote Th17 differentiation by targeting and depleting SMAD-7, a negative regulator of TGF- $\beta$ signaling [166]. miR-21, for instance, suppresses SMAD7 thus influencing TGF $\beta$ led signaling to promote Th17 differentiation [166]. Upregulated miR-21 also represses IL-12, which acts as a strong inducer of Th1 responses thus reducing IFN $\gamma$ production and a reduction in Th1:Th2 ratio in T-cell production [364] demonstrating that this interaction supports the notion that miR-21 controls the balance of pro- and anti-inflammatory responses [165]. Upregulated miR-21 also suppresses production of the potent antiviral cytokine IFN by repressing MYD88/IRAK [164]. Conversely, miR-21 expression can promote NFKB activation and TNF- $\alpha$ and IFN $\gamma$ production in activated T-cells clearly acting to induce inflammation on recognition of transformed tumor-cells [365].

\subsection{Other Key MIR and Immune Pathways Dysregulated by HBx in HBV-HCC}

Dysregulation of miR-29 occurs in lung, breast and colon cancer [366-368]. HBx-upregulated miR-29a/b is widely reported in miRNA modulation of HBV-HCC pathogenesis by targeting genes like PTEN/PI3K/AKT/MMP-2 in HBV-HCC, thus contributing towards the promotion of cell migration and invasion $[127,276]$. The miR-29a/b cluster plays a crucial role in the thymic production of T-cells, T-cell differentiation and B-cell oncogenic transformation [277]. In the presence of infection, this family of miRNA modulates type 1 IFN signaling and T-BET/EOMES expression promoting Th1 CD4+ differentiation over Th2 differentiation. Downregulated miR-29a/b, for instance, fails to block type 1 IFN/T-BET/EOMES thus promoting Th1 CD4+ differentiation. Conversely, upregulated miR-29a/b blocks type 1 IFN/T-BET/EOMES to promote equal expression of Th1 and Th2. However, in HBV-HCC $\mathrm{miR}-29 \mathrm{a} / \mathrm{b}$ is upregulated by the HBx protein, suggesting a viral intervention to promote a balanced expression of Th1 and Th2. A similar role is played by miR-29a/b when this miRNA is downregulated by intracellular bacteria and fails to modulate type 1 IFN resulting in an imbalance of the production of CD8+ T-cell [277].

Dysregulation of miR-34 has been reported in colon, breast and lung cancer [369-371]. Another HBx-dysregulated miRNA, miR-34, acts across the entire HBV-HCC continuum and is upregulated in early HBV infection/inflammation [24] and in HBV induced fibrosis [372]. However, miR-34 is widely reported as relatively downregulated in HBV-HC playing a role in the modulation of metastasis, growth and apoptosis [188]. The HBx protein can repress p53 stimulated miR-34 in hepatocytes leading to an upregulation of macrophage-derived chemokine (CCL22) stimulated regulatory T-cells (Tregs). Tregs, in turn, can block effector T-cells thus allowing HBV expression to increase $[24,187]$. Upregulated p53 induced miR-34a is also reported to suppress FOXP1 resulting in the inhibition of pro-B cell to pre-B cell transition [193]; however, if HBx suppresses p53 led stimulation of miR-34a [24] then the consequent will be different. 


\section{Conclusions}

In this extensive review we have attempted to bring together studies that have shown the complex interlinking roles of miRNA in HBV-HCC pathogenesis and the immune response, both innate and adaptive. Moreover, from the literature it is evident that nearly all HBx-dysregulated miRNA in HBV-HCC can additionally act on multiple immune targets (Tables 1 and 2). Using four key miRNA as an illustration, it is clear that there is simultaneous modulation of central pathways, namely, the principal HBV-HCC cancer pathways and those of the innate and adaptive immune systems (Figures 1-4). We, therefore, hypothesize that the same specific miRNA that are dysregulated in hepatocytes during HBV-HCC pathogenesis can become simultaneously and interdependently dysregulated in immune cells and vice versa. The four representative miRNA selected primarily demonstrate how they modulate HBV replication and oncogene or tumor suppressor expression in HBV-HCC pathogenesis while simultaneously modulating the proliferation and differentiation of leucocytes in the innate and adaptive immune systems. This interplay between the two pathways may provide us with the possibility of using candidate miRNA to manipulate this interaction as a potential therapeutic option.

Multiple miRNA target the same genes and post-transcriptional gene silencing of translation is a collective effort. Even then it is likely miRNA only exert a mild secondary influence on mRNA stability and translation in response to the stochastic nature of gene expression and changing environmental influences [7]. Furthermore, small tumors $(<0.5 \mathrm{~cm})$ would be unable by themselves to alter the level of extracellular miRNA in sera and the explanation for dysregulated miRNA in early stage carcinogenesis would likely be as a result of general immune responses [373]. In vivo results also indicate that most RNA-based therapies are compromised by non-specific organ bio-distribution, reticuloendothelial system (RES) clearance, and endolysosomal trafficking [374]. Increasingly, future studies will need to consider the selection of sub-populations of extracellular vesicles that facilitate small RNA messaging. Emerging research indicates that only certain types of encapsulated miRNA play a role in cell-cell signaling and others may not. Exosomes, for instance, appear to transport miRNA that promote paracrine communication [375-377] and nanotechnology can be used to deliver chemically modified miRNA to cancer cells [378,379].

This rather simplistic account cannot illustrate the full extent of the dynamic, complex and multi-dimensional role of each miRNA in varying HBV-HCC cases either with respect to the varying degrees of expression in each pathway or the degree to which HBV-HCC pathogenesis can be modulated. However, the demonstration of these interrelationships will allow each of these potential interactions to be treated as hypotheses that need to be tested individually. Although miRNA hold promise as therapeutic agents in various cancers including HBV-associated HCC, this field of study remains a work in progress that is yet to be fully exploited [380].

Author Contributions: K.S.-conceptualization of article, preparation of first draft, development of figures, writing and review; L.S.— writing and review; P.A.—writing, review; J.M.-writing and review; C.W.-writing and review; A.C.- -writing and review; A.K.- writing and review. All authors have read and agreed to the published version of the manuscript.

Funding: L.S. has received funding in part from a Medical Research Foundation research grant award (MRF-044-0001-RG-SWADL). P.A. and C.W. have been funded in part with Federal funds from the Frederick National Laboratory for Cancer Research, National Institutes of Health (HHSN261200800001E), the Intramural Research Program of the NIH (Frederick National Lab, Center for Cancer Research). The content of this review does not necessarily reflect the views or policies of the Department of Health and Human Services, nor does mention of trade names, commercial products, or organizations imply endorsement by the US Government. J.M. has received funding in part from within the Basic Research Program at HSE University and funded by the Russian Academic Excellence Project '5-100' and A.K. has received funding from the Cancer Association of South Africa (CANSA).

Conflicts of Interest: The authors declare no conflicts of interest. 


\section{References}

1. Jemal, A.; Bray, F.; Center, M.M.; Ferlay, J.; Ward, E.; Forman, D. Global cancer statistics. CA A Cancer J. Clin. 2011, 61, 69-90. [CrossRef] [PubMed]

2. Gomaa, A.I.; Khan, S.A.; Toledano, M.B.; Waked, I.; Taylor-Robinson, S.D. Hepatocellular carcinoma: Epidemiology, risk factors and pathogenesis. World J. Gastroenterol. WJG 2008, 14, 4300. [CrossRef] [PubMed]

3. El-Serag, H.B. Epidemiology of viral hepatitis and hepatocellular carcinoma. Gastroenterology 2012, 142, 1264-1273. [CrossRef] [PubMed]

4. Lemoine, M.; Thursz, M.R. Battlefield against hepatitis B infection and HCC in Africa. J. Hepatol. 2017, 66, 645-654. [CrossRef]

5. Ringelhan, M.; O'connor, T.; Protzer, U.; Heikenwalder, M. The direct and indirect roles of HBV in liver cancer: Prospective markers for HCC screening and potential therapeutic targets. J. Pathol. 2015, 235, 355-367. [CrossRef]

6. Xiao, C.; Rajewsky, K. MicroRNA control in the immune system: Basic principles. Cell 2009, 136, 26-36. [CrossRef]

7. Vidigal, J.A.; Ventura, A. The biological functions of miRNAs: Lessons from in vivo studies. Trends Cell Biol. 2015, 25, 137-147. [CrossRef]

8. Sartorius, K.; Makarova, J.; Sartorius, B.; An, P.; Winkler, C.; Chuturgoon, A.; Kramvis, A. The regulatory role of microRNA in Hepatitis-B Virus-Associated Hepatocellular Carcinoma (HBV-HCC) pathogenesis. Cells 2019, 8, 1504. [CrossRef]

9. Lu, L.F.; Liston, A. MicroRNA in the immune system, microRNA as an immune system. Immunology 2009, 127, 291-298. [CrossRef]

10. Ganem, D.; Prince, A.M. Hepatitis B virus infection-natural history and clinical consequences. N. Engl. J. Med. 2004, 350, 1118-1129. [CrossRef]

11. Liu, W.-H.; Yeh, S.-H.; Chen, P.-J. Role of microRNAs in hepatitis B virus replication and pathogenesis. Biochim. Biophys. Acta BBA Gene Regul. Mech. 2011, 1809, 678-685. [CrossRef] [PubMed]

12. Mak, D.; de Villiers, C.B.; Chasela, C.; Urban, M.I.; Kramvis, A. Analysis of risk factors associated with hepatocellular carcinoma in black South Africans: 2000-2012. PLoS ONE 2018, 13, e0196057. [CrossRef] [PubMed]

13. Bréchot, C. Pathogenesis of hepatitis B virus-related hepatocellular carcinoma: Old and new paradigms. Gastroenterology 2004, 127, S56-S61. [CrossRef] [PubMed]

14. Jiang, J.; Gusev, Y.; Aderca, I.; Mettler, T.A.; Nagorney, D.M.; Brackett, D.J.; Roberts, L.R.; Schmittgen, T.D. Association of MicroRNA expression in hepatocellular carcinomas with hepatitis infection, cirrhosis, and patient survival. Clin. Cancer Res. 2008, 14, 419-427. [CrossRef] [PubMed]

15. Clippinger, A.J.; Gearhart, T.L.; Bouchard, M.J. Hepatitis B virus X protein modulates apoptosis in primary rat hepatocytes by regulating both NF-kappaB and the mitochondrial permeability transition pore. J. Virol. 2009, 83, 4718-4731. [CrossRef] [PubMed]

16. Gearhart, T.L.; Bouchard, M.J. The hepatitis B virus X protein modulates hepatocyte proliferation pathways to stimulate viral replication. J. Virol. 2010, 84, 2675-2686. [CrossRef]

17. Gearhart, T.L.; Bouchard, M.J. Replication of the hepatitis B virus requires a calcium-dependent HBx-induced G1 phase arrest of hepatocytes. Virology 2010, 407, 14-25. [CrossRef]

18. Rawat, S.; Bouchard, M.J. The hepatitis B virus (HBV) HBx protein activates AKT to simultaneously regulate HBV replication and hepatocyte survival. J. Virol. 2015, 89, 999-1012. [CrossRef]

19. Wei, Y.; Neuveut, C.; Tiollais, P.; Buendia, M.-A. Molecular biology of the hepatitis B virus and role of the X gene. Pathol. Biol. 2010, 58, 267-272. [CrossRef]

20. Arbuthnot, P.; Capovilla, A.; Kew, M. Putative role of hepatitis B virus X protein in hepatocarcinogenesis: Effects on apoptosis, DNA repair, mitogen-activated protein kinase and JAK/STAT pathways. J. Gastroenterol. Hepatol. 2000, 15, 357-368. [CrossRef]

21. Bouchard, M.J.; Schneider, R.J. The enigmatic X gene of hepatitis B virus. J. Virol. 2004, 78, $12725-12734$. [CrossRef] [PubMed]

22. Ali, A.; Abdel-Hafiz, H.; Suhail, M.; Al-Mars, A.; Zakaria, M.K.; Fatima, K.; Ahmad, S.; Azhar, E.; Chaudhary, A.; Qadri, I. Hepatitis B virus, HBx mutants and their role in hepatocellular carcinoma. World J. Gastroenterol. WJG 2014, 20, 10238. [CrossRef] [PubMed] 
23. Bui-Nguyen, T.M.; Pakala, S.B.; Sirigiri, D.R.; Martin, E.; Murad, F.; Kumar, R. Stimulation of inducible nitric oxide by hepatitis B virus transactivator protein HBx requires MTA1 coregulator. J. Biol. Chem. 2016, 291, 1198. [CrossRef]

24. Xie, K.-L.; Zhang, Y.-G.; Liu, J.; Zeng, Y.; Wu, H. MicroRNAs associated with HBV infection and HBV-related HCC. Theranostics 2014, 4, 1176. [CrossRef] [PubMed]

25. Hatziapostolou, M.; Polytarchou, C.; Aggelidou, E.; Drakaki, A.; Poultsides, G.A.; Jaeger, S.A.; Ogata, H.; Karin, M.; Struhl, K.; Hadzopoulou-Cladaras, M.; et al. An HNF4 $\alpha$-miRNA inflammatory feedback circuit regulates hepatocellular oncogenesis. Cell 2011, 147, 1233-1247. [CrossRef]

26. Murakami, Y.; Yasuda, T.; Saigo, K.; Urashima, T.; Toyoda, H.; Okanoue, T.; Shimotohno, K. Comprehensive analysis of microRNA expression patterns in hepatocellular carcinoma and non-tumorous tissues. Oncogene 2006, 25, 2537. [CrossRef]

27. Mizuguchi, Y.; Takizawa, T.; Yoshida, H.; Uchida, E. Dysregulated miRNA in progression of hepatocellular carcinoma: A systematic review. Hepatol. Res. 2016, 46, 391-406. [CrossRef]

28. Szabo, G.; Bala, S. MicroRNAs in liver disease. Nat. Rev. Gastroenterol. Hepatol. 2013, 10, 542-552. [CrossRef]

29. Hou, X.; Liang, Y.; Chen, J.; Wei, Y.; Zeng, P.; Wang, L.; Lu, C.; Diao, H. Expression profiling of cellular microRNA in asymptomatic HBsAg carriers and chronic hepatitis B patients. BioMed Res. Int. 2017, 2017. [CrossRef]

30. Ji, F.; Yang, B.; Peng, X.; Ding, H.; You, H.; Tien, P. Circulating microRNAs in hepatitis B virus-infected patients. J. Viral Hepat. 2011, 18. [CrossRef]

31. Gack, M.U. What viruses can teach us about the human immune system. PLoS Pathog. 2017, 13 , e1006364. [CrossRef] [PubMed]

32. Huang, Y.; Dai, H.; Ke, R. Principles of robust innate immune response to viral infections: A multiplex network analysis. Front. Immunol. 2019, 10, 1736. [CrossRef] [PubMed]

33. Suslov, A.; Boldanova, T.; Wang, X.; Wieland, S.; Heim, M.H. Hepatitis B virus does not interfere with innate immune responses in the human liver. Gastroenterology 2018, 154, 1778-1790. [CrossRef] [PubMed]

34. Ferrari, C. HBV and the immune response. Liver Int. 2015, 35, 121-128. [CrossRef] [PubMed]

35. Wieland, S.; Thimme, R.; Purcell, R.H.; Chisari, F.V. Genomic analysis of the host response to hepatitis B virus infection. Proc. Natl. Acad. Sci. USA 2004, 101, 6669-6674. [CrossRef]

36. Bertoletti, A.; Maini, M.K.; Ferrari, C. The host-pathogen interaction during HBV infection: Immunological controversies. Antivir. Ther. 2010, 15, 15. [CrossRef]

37. Fisicaro, P.; Valdatta, C.; Boni, C.; Massari, M.; Mori, C.; Zerbini, A.; Orlandini, A.; Sacchelli, L.; Missale, G.; Ferrari, C. Early kinetics of innate and adaptive immune responses during hepatitis B virus infection. Gut 2009, 58, 974-982. [CrossRef]

38. Bertoletti, A.; Kennedy, P.T. The immune tolerant phase of chronic HBV infection: New perspectives on an old concept. Cell. Mol. Immunol. 2015, 12, 258. [CrossRef]

39. Bertoletti, A.; Ferrari, C. Adaptive immunity in HBV infection. J. Hepatol. 2016, 64, S71-S83. [CrossRef]

40. Kumar, A. Innate immune responses in hepatitis B virus (HBV) infection. Virol. J. 2014, 11, 22.

41. Hui, C.-K.; Lau, G.K. Immune system and hepatitis B virus infection. J. Clin. Virol. 2005, 34, S44-S48. [CrossRef]

42. Jung, M.-C.; Pape, G.R. Immunology of hepatitis B infection. Lancet Infect. Dis. 2002, 2, 43-50. [CrossRef]

43. Ferrari, C.; Penna, A.; Bertoletti, A.; Valli, A.; Antoni, A.D.; Giuberti, T.; Cavalli, A.; Petit, M.; Fiaccadori, F. Cellular immune response to hepatitis B virus-encoded antigens in acute and chronic hepatitis $B$ virus infection. J. Immunol. 1990, 145, 3442-3449. [PubMed]

44. Maini, M.K.; Gehring, A.J. The role of innate immunity in the immunopathology and treatment of HBV infection. J. Hepatol. 2016, 64, S60-S70. [CrossRef] [PubMed]

45. Bénéchet, A.P.; De Simone, G.; Di Lucia, P.; Cilenti, F.; Barbiera, G.; Le Bert, N.; Fumagalli, V.; Lusito, E.; Moalli, F.; Bianchessi, V.; et al. Dynamics and genomic landscape of CD8+ T cells undergoing hepatic priming. Nature 2019, 574, 200-205. [CrossRef]

46. Zhao, Y.; Shao, Q.; Peng, G. Exhaustion and senescence: Two crucial dysfunctional states of T cells in the tumor microenvironment. Cell. Mol. Immunol. 2019, 1-9. [CrossRef]

47. Suzuki, H.; Katsura, A.; Matsuyama, H.; Miyazono, K. MicroRNA regulons in tumor microenvironment. Oncogene 2015, 34, 3085-3094. [CrossRef] 
48. Croce, C.M. Causes and consequences of microRNA dysregulation in cancer. Nat. Rev. Genet. 2009, $10,704$. [CrossRef]

49. Li, X.; Wu, Z.; Fu, X.; Han, W. A microRNA component of the neoplastic microenvironment: Microregulators with far-reaching impact. BioMed Res. Int. 2012, 2013. [CrossRef]

50. Ma, L.; Young, J.; Prabhala, H.; Pan, E.; Mestdagh, P.; Muth, D.; Teruya-Feldstein, J.; Reinhardt, F.; Onder, T.T.; Valastyan, S.; et al. MiR-9, a MYC/MYCN-activated microRNA, regulates E-cadherin and cancer metastasis. Nat. Cell Biol. 2010, 12, 247-256. [CrossRef]

51. Png, K.J.; Halberg, N.; Yoshida, M.; Tavazoie, S.F. A microRNA regulon that mediates endothelial recruitment and metastasis by cancer cells. Nature 2012, 481, 190-194. [CrossRef] [PubMed]

52. Matsuyama, H.; Suzuki, H.I.; Nishimori, H.; Noguchi, M.; Yao, T.; Komatsu, N.; Mano, H.; Sugimoto, K.; Miyazono, K. MiR-135b mediates NPM-ALK-driven oncogenicity and renders IL-17-producing immunophenotype to anaplastic large cell lymphoma. Blood J. Am. Soc. Hematol. 2011, 118, 6881-6892. [CrossRef]

53. Mitra, A.K.; Zillhardt, M.; Hua, Y.; Tiwari, P.; Murmann, A.E.; Peter, M.E.; Lengyel, E. MicroRNAs reprogram normal fibroblasts into cancer-associated fibroblasts in ovarian cancer. Cancer Discov. 2012, 2, 1100-1108. [CrossRef] [PubMed]

54. Kalluri, R.; Zeisberg, M. Fibroblasts in cancer. Nat. Rev. Cancer 2006, 6, 392-401. [CrossRef] [PubMed]

55. Chou, J.; Lin, J.H.; Brenot, A.; Kim, J.-W.; Provot, S.; Werb, Z. GATA3 suppresses metastasis and modulates the tumour microenvironment by regulating microRNA-29b expression. Nat. Cell Biol. 2013, 15, 201. [CrossRef] [PubMed]

56. Schulte, L.N.; Westermann, A.J.; Vogel, J. Differential activation and functional specialization of miR-146 and miR-155 in innate immune sensing. Nucleic Acids Res. 2013, 41, 542-553. [CrossRef]

57. Schulz, W.A. Molecular Biology of Human Cancers: An Advanced Student's Textbook; Springer Science \& Business Media: New York, NY, USA, 2005.

58. Garzon, R.; Marcucci, G.; Croce, C.M. Targeting microRNAs in cancer: Rationale, strategies and challenges. Nat. Rev. Drug Discov. 2010, 9, 775-789. [CrossRef]

59. Wu, G.; Huang, P.; Ju, X.; Li, Z.; Wang, Y. Lin28B over-expression mediates the repression of let-7 by hepatitis B virus $X$ protein in hepatoma cells. Int. J. Clin. Exp. Med. 2015, 8, 15108.

60. Wang, Y.; Lu, Y.; Toh, S.T.; Sung, W.-K.; Tan, P.; Chow, P.; Chung, A.Y.; Jooi, L.L.; Lee, C.G. Lethal-7 is down-regulated by the hepatitis $\mathrm{B}$ virus $\mathrm{x}$ protein and targets signal transducer and activator of transcription 3. J. Hepatol. 2010, 53, 57-66. [CrossRef]

61. Jiang, X.; Kanda, T.; Wu, S.; Nakamura, M.; Miyamura, T.; Nakamoto, S.; Banerjee, A.; Yokosuka, O. Regulation of microRNA by hepatitis B virus infection and their possible association with control of innate immunity. World J. Gastroenterol. WJG 2014, 20, 7197. [CrossRef]

62. Takata, A.; Otsuka, M.; Ohno, M.; Kishikawa, T.; Yoshikawa, T.; Koike, K. Mutual antagonism between hepatitis B viral mRNA and host microRNA let-7. Sci. Rep. 2016, 6, 23237. [CrossRef] [PubMed]

63. Witwer, K.W.; Sisk, J.M.; Gama, L.; Clements, J.E. MicroRNA regulation of IFN- $\beta$ protein expression: Rapid and sensitive modulation of the innate immune response. J. Immunol. 2010, 184, 2369-2376. [CrossRef] [PubMed]

64. Boyerinas, B.; Park, S.-M.; Shomron, N.; Hedegaard, M.M.; Vinther, J.; Andersen, J.S.; Feig, C.; Xu, J.; Burge, C.B.; Peter, M.E. Identification of let-7-regulated oncofetal genes. Cancer Res. 2008, 68, 2587-2591. [CrossRef] [PubMed]

65. O'connell, R.M.; Rao, D.S.; Chaudhuri, A.A.; Baltimore, D. Physiological and pathological roles for microRNAs in the immune system. Nat. Rev. Immunol. 2010, 10, 111-122. [CrossRef] [PubMed]

66. Shimizu, S.; Takehara, T.; Hikita, H.; Kodama, T.; Miyagi, T.; Hosui, A.; Tatsumi, T.; Ishida, H.; Noda, T.; Nagano, H.; et al. The let-7 family of microRNAs inhibits Bcl-xL expression and potentiates sorafenib-induced apoptosis in human hepatocellular carcinoma. J. Hepatol. 2010, 52, 698-704. [CrossRef]

67. Challen, G.A.; Boles, N.C.; Chambers, S.M.; Goodell, M.A. Distinct hematopoietic stem cell subtypes are differentially regulated by TGF- $\beta 1$. Cell Stem Cell 2010, 6, 265-278. [CrossRef]

68. Emmrich, S.; Rasche, M.; Schöning, J.; Reimer, C.; Keihani, S.; Maroz, A.; Xie, Y.; Li, Z.; Schambach, A.; Reinhardt, D.; et al. MiR-99a/100 125b tricistrons regulate hematopoietic stem and progenitor cell homeostasis by shifting the balance between TGF $\beta$ and Wnt signaling. Genes Dev. 2014, 28, 858-874. [CrossRef] 
69. Luis, T.C.; Naber, B.A.; Roozen, P.P.; Brugman, M.H.; De Haas, E.F.; Ghazvini, M.; Fibbe, W.E.; Van Dongen, J.J.; Fodde, R.; Staal, F.J. Canonical wnt signaling regulates hematopoiesis in a dosage-dependent fashion. Cell Stem Cell 2011, 9, 345-356. [CrossRef]

70. Copley, M.R.; Babovic, S.; Benz, C.; Knapp, D.J.; Beer, P.A.; Kent, D.G.; Wohrer, S.; Treloar, D.Q.; Day, C.; Rowe, K.; et al. The Lin28b-let-7-Hmga2 axis determines the higher self-renewal potential of fetal haematopoietic stem cells. Nat. Cell Biol. 2013, 15, 916-925. [CrossRef]

71. Yuan, J.; Nguyen, C.K.; Liu, X.; Kanellopoulou, C.; Muljo, S.A. Lin28b reprograms adult bone marrow hematopoietic progenitors to mediate fetal-like lymphopoiesis. Science 2012, 335, 1195-1200. [CrossRef]

72. Pobezinsky, L.A.; Etzensperger, R.; Jeurling, S.; Alag, A.; Kadakia, T.; McCaughtry, T.M.; Kimura, M.Y.; Sharrow, S.O.; Guinter, T.I.; Feigenbaum, L.; et al. Let-7 microRNAs target the lineage-specific transcription factor PLZF to regulate terminal NKT cell differentiation and effector function. Nat. Immunol. 2015, 16, 517. [CrossRef] [PubMed]

73. Lu, J.-W.; Liao, C.-Y.; Yang, W.-Y.; Lin, Y.-M.; Jin, S.-L.C.; Wang, H.-D.; Yuh, C.-H. Overexpression of endothelin 1 triggers hepatocarcinogenesis in zebrafish and promotes cell proliferation and migration through the AKT pathway. PLoS ONE 2014, 9, e85318. [CrossRef] [PubMed]

74. Zhang, X.; Zhang, E.; Ma, Z.; Pei, R.; Jiang, M.; Schlaak, J.F.; Roggendorf, M.; Lu, M. Modulation of hepatitis B virus replication and hepatocyte differentiation by MicroRNA-1. Hepatology 2011, 53, 1476-1485. [CrossRef] [PubMed]

75. Datta, J.; Kutay, H.; Nasser, M.W.; Nuovo, G.J.; Wang, B.; Majumder, S.; Liu, C.-G.; Volinia, S.; Croce, C.M.; Schmittgen, T.D.; et al. Methylation mediated silencing of MicroRNA-1 gene and its role in hepatocellular carcinogenesis. Cancer Res. 2008, 68, 5049-5058. [CrossRef] [PubMed]

76. Chen, J.-F.; Mandel, E.M.; Thomson, J.M.; Wu, Q.; Callis, T.E.; Hammond, S.M.; Conlon, F.L.; Wang, D.-Z. The role of microRNA-1 and microRNA-133 in skeletal muscle proliferation and differentiation. Nat. Genet. 2006, 38, 228-233. [CrossRef]

77. Wei, X.; Xiang, T.; Ren, G.; Tan, C.; Liu, R.; Xu, X.; Wu, Z. MiR-101 is down-regulated by the hepatitis B virus $\mathrm{x}$ protein and induces aberrant DNA methylation by targeting DNA methyltransferase 3A. Cell. Signal. 2013, 25, 439-446. [CrossRef]

78. Xie, Y.; Yao, Q.; Butt, A.M.; Guo, J.; Tian, Z.; Bao, X.; Li, H.; Meng, Q.; Lu, J. Expression profiling of serum microRNA-101 in HBV-associated chronic hepatitis, liver cirrhosis, and hepatocellular carcinoma. Cancer Biol. Ther. 2014, 15, 1248-1255. [CrossRef]

79. Au, S.L.K.; Wong, C.C.L.; Lee, J.M.F.; Fan, D.N.Y.; Tsang, F.H.; Ng, I.O.L.; Wong, C.M. Enhancer of zeste homolog 2 epigenetically silences multiple tumor suppressor microRNAs to promote liver cancer metastasis. Hepatology 2012, 56, 622-631. [CrossRef]

80. Li, S.; Fu, H.; Wang, Y.; Tie, Y.; Xing, R.; Zhu, J.; Sun, Z.; Wei, L.; Zheng, X. MicroRNA-101 regulates expression of the v-fos FBJ murine osteosarcoma viral oncogene homolog (FOS) oncogene in human hepatocellular carcinoma. Hepatology 2009, 49, 1194-1202. [CrossRef]

81. Fu, Y.; Wei, X.; Tang, C.; Li, J.; Liu, R.; Shen, A.; Wu, Z. Circulating microRNA-101 as a potential biomarker for hepatitis B virus-related hepatocellular carcinoma. Oncol. Lett. 2013, 6, 1811-1815. [CrossRef]

82. He, H.; Tian, W.; Chen, H.; Deng, Y. MicroRNA-101 sensitizes hepatocellular carcinoma cells to doxorubicin-induced apoptosis via targeting Mcl-1. Mol. Med. Rep. 2016, 13, 1923-1929. [CrossRef] [PubMed]

83. Sheng, Y.; Ding, S.; Chen, K.; Chen, J.; Wang, S.; Zou, C.; Zhang, J.; Cao, Y.; Huang, A.; Tang, H. Functional analysis of miR-101-3p and Rap1b involved in hepatitis B virus-related hepatocellular carcinoma pathogenesis. Biochem. Cell Biol. 2014, 92, 152-162. [CrossRef] [PubMed]

84. Shen, S.; Lin, Y.; Yuan, X.; Shen, L.; Chen, J.; Chen, L.; Qin, L.; Shen, B. Biomarker MicroRNAs for diagnosis, prognosis and treatment of hepatocellular carcinoma: A functional survey and comparison. Sci. Rep. 2016, 6, 38311. [CrossRef] [PubMed]

85. Liang, H.-W.; Wang, N.; Wang, Y.; Wang, F.; Fu, Z.; Yan, X.; Zhu, H.; Diao, W.; Ding, Y.; Chen, X.; et al. Hepatitis B virus-human chimeric transcript HBx-LINE1 promotes hepatic injury via sequestering cellular microRNA-122. J. Hepatol. 2016, 64, 278-291. [CrossRef]

86. Yoshikawa, T.; Takata, A.; Otsuka, M.; Kishikawa, T.; Kojima, K.; Yoshida, H.; Koike, K. Silencing of microRNA-122 enhances interferon- $\alpha$ signaling in the liver through regulating SOCS3 promoter methylation. Sci. Rep. 2012, 2, 637. [CrossRef] 
87. Stelma, F.; Van Der Ree, M.H.; Sinnige, M.J.; Brown, A.; Swadling, L.; De Vree, J.M.L.; Willemse, S.B.; Van Der Valk, M.; Grint, P.; Neben, S.; et al. Immune phenotype and function of natural killer and T cells in chronic hepatitis C patients who received a single dose of anti-MicroRNA-122, RG-101. Hepatology 2017, 66, 57-68. [CrossRef]

88. Lin, C.J.-F.; Gong, H.-Y.; Tseng, H.-C.; Wang, W.-L.; Wu, J.-L. MiR-122 targets an anti-apoptotic gene, Bcl-w, in human hepatocellular carcinoma cell lines. Biochem. Biophys. Res. Commun. 2008, 375, 315-320. [CrossRef]

89. Wang, S.; Qiu, L.; Yan, X.; Jin, W.; Wang, Y.; Chen, L.; Wu, E.; Ye, X.; Gao, G.F.; Wang, F.; et al. Loss of microRNA 122 expression in patients with hepatitis B enhances hepatitis B virus replication through cyclin G1-modulated P53 activity. Hepatology 2012, 55, 730-741. [CrossRef]

90. Song, K.; Han, C.; Zhang, J.; Lu, D.; Dash, S.; Feitelson, M.; Lim, K.; Wu, T. Epigenetic regulation of MicroRNA-122 by peroxisome proliferator activated receptor-gamma and hepatitis $\mathrm{b}$ virus $\mathrm{X}$ protein in hepatocellular carcinoma cells. Hepatology 2013, 58, 1681-1692. [CrossRef]

91. Yu, G.; Chen, X.; Chen, S.; Ye, W.; Hou, K.; Liang, M. MiR-19a, miR-122 and miR-223 are differentially regulated by hepatitis B virus $\mathrm{X}$ protein and involve in cell proliferation in hepatoma cells. J. Transl. Med. 2016, 14, 122. [CrossRef]

92. Peng, F.; Xiao, X.; Jiang, Y.; Luo, K.; Tian, Y.; Peng, M.; Zhang, M.; Xu, Y.; Gong, G. HBx down-regulated Gld2 plays a critical role in HBV-related dysregulation of miR-122. PLoS ONE 2014, 9, e92998. [CrossRef] [PubMed]

93. Fan, C.-G.; Wang, C.-M.; Tian, C.; Wang, Y.; Li, L.; Sun, W.-S.; Li, R.-F.; Liu, Y.-G. MiR-122 inhibits viral replication and cell proliferation in hepatitis B virus-related hepatocellular carcinoma and targets NDRG3. Oncol. Rep. 2011, 26, 1281-1286. [PubMed]

94. Fornari, F.; Gramantieri, L.; Giovannini, C.; Veronese, A.; Ferracin, M.; Sabbioni, S.; Calin, G.A.; Grazi, G.L.; Croce, C.M.; Tavolari, S.; et al. MiR-122/cyclin G1 interaction modulates p53 activity and affects doxorubicin sensitivity of human hepatocarcinoma cells. Cancer Res. 2009, 69, 5761-5767. [CrossRef] [PubMed]

95. Wu, Q.; Liu, H.-O.; Liu, Y.-D.; Liu, W.-S.; Pan, D.; Zhang, W.-J.; Yang, L.; Fu, Q.; Xu, J.-J.; Gu, J.-X. Decreased expression of hepatocyte nuclear factor $4 \alpha(\mathrm{Hnf} 4 \alpha)$ /microRNA-122 (miR-122) axis in hepatitis B virus-associated hepatocellular carcinoma enhances potential oncogenic GALNT10 protein activity. J. Biol. Chem. 2015, 290, 1170-1185. [CrossRef]

96. Li, C.; Wang, Y.; Wang, S.; Wu, B.; Hao, J.; Fan, H.; Ju, Y.; Ding, Y.; Chen, L.; Chu, X.; et al. Hepatitis B virus mRNA-mediated miR-122 inhibition upregulates PTTG1-binding protein, which promotes hepatocellular carcinoma tumor growth and cell invasion. J. Virol. 2013, 87, 2193-2205. [CrossRef]

97. Gramantieri, L.; Ferracin, M.; Fornari, F.; Veronese, A.; Sabbioni, S.; Liu, C.-G.; Calin, G.A.; Giovannini, C.; Ferrazzi, E.; Grazi, G.L.; et al. Cyclin G1 is a target of miR-122a, a microRNA frequently down-regulated in human hepatocellular carcinoma. Cancer Res. 2007, 67, 6092-6099. [CrossRef]

98. Coulouarn, C.; Factor, V.M.; Andersen, J.B.; Durkin, M.E.; Thorgeirsson, S.S. Loss of miR-122 expression in liver cancer correlates with suppression of the hepatic phenotype and gain of metastatic properties. Oncogene 2009, 28, 3526-3536. [CrossRef]

99. Adams, C.M.; Kim, A.S.; Mitra, R.; Choi, J.K.; Gong, J.Z.; Eischen, C.M. BCL-W has a fundamental role in B cell survival and lymphomagenesis. J. Clin. Investig. 2017, 127, 635-650. [CrossRef]

100. Lu, Y.; Yue, X.; Cui, Y.; Zhang, J.; Wang, K. MicroRNA-124 suppresses growth of human hepatocellular carcinoma by targeting STAT3. Biochem. Biophys. Res. Commun. 2013, 441, 873-879. [CrossRef]

101. Qin, Z.; Wang, P.-Y.; Su, D.-F.; Liu, X. MiRNA-124 in immune system and immune disorders. Front. Immunol. 2016, 7, 406. [CrossRef]

102. Meng, F.; Henson, R.; Wehbe-Janek, H.; Ghoshal, K.; Jacob, S.T.; Patel, T. MicroRNA-21 regulates expression of the PTEN tumor suppressor gene in human hepatocellular cancer. Gastroenterology 2007, 133, 647-658. [CrossRef] [PubMed]

103. Dickstein, J.; Senyuk, V.; Premanand, K.; Laricchia-Robbio, L.; Xu, P.; Cattaneo, F.; Fazzina, R.; Nucifora, G. Methylation and silencing of miRNA-124 by EVI1 and self-renewal exhaustion of hematopoietic stem cells in murine myelodysplastic syndrome. Proc. Natl. Acad. Sci. USA 2010, 107, 9783-9788. [CrossRef]

104. Liu, W.; Hu, J.; Zhou, K.; Chen, F.; Wang, Z.; Liao, B.; Dai, Z.; Cao, Y.; Fan, J.; Zhou, J. Serum exosomal miR-125b is a novel prognostic marker for hepatocellular carcinoma. OncoTargets Ther. 2017, 10, 3843. [CrossRef] [PubMed] 
105. Malumbres, R.; Tibshirani, R.; Cubedo, E.; Sarosiek, K.A.; Jiang, X.; Ruiz, J.; Lossos, I. Differentiation-Stage-Specific Expression of MicroRNAs in B-Lymphocytes and Diffuse Large B-Cell Lymphomas (DLBCL). Blood 2008. [CrossRef]

106. Tili, E.; Michaille, J.-J.; Cimino, A.; Costinean, S.; Dumitru, C.D.; Adair, B.; Fabbri, M.; Alder, H.; Liu, C.G.; Calin, G.A.; et al. Modulation of miR-155 and miR-125b levels following lipopolysaccharide/TNF- $\alpha$ stimulation and their possible roles in regulating the response to endotoxin shock. J. Immunol. 2007, 179, 5082-5089. [CrossRef] [PubMed]

107. Zhao, A.; Zeng, Q.; Xie, X.; Zhou, J.; Yue, W.; Li, Y.; Pei, X. MicroRNA-125b induces cancer cell apoptosis through suppression of Bcl-2 expression. J. Genet. Genom. 2012, 39, 29-35. [CrossRef] [PubMed]

108. Ooi, A.L.; Sahoo, D.; Adorno, M.; Wang, Y.; Weissman, I.L.; Park, C.Y. MicroRNA-125b expands hematopoietic stem cells and enriches for the lymphoid-balanced and lymphoid-biased subsets. Proc. Natl. Acad. Sci. USA 2010, 107, 21505-21510. [CrossRef]

109. Gentner, B.; Visigalli, I.; Hiramatsu, H.; Lechman, E.; Ungari, S.; Giustacchini, A.; Schira, G.; Amendola, M.; Quattrini, A.; Martino, S.; et al. Identification of hematopoietic stem cell-specific miRNAs enables gene therapy of globoid cell leukodystrophy. Sci. Transl. Med. 2010, 2. [CrossRef]

110. So, A.Y.-L.; Sookram, R.; Chaudhuri, A.A.; Minisandram, A.; Cheng, D.; Xie, C.; Lim, E.L.; Flores, Y.G.; Jiang, S.; Kim, J.T.; et al. Dual mechanisms by which miR-125b represses IRF4 to induce myeloid and B-cell leukemias. Blood J. Am. Soc. Hematol. 2014, 124, 1502-1512. [CrossRef]

111. Chaudhuri, A.A.; So, A.Y.-L.; Mehta, A.; Minisandram, A.; Sinha, N.; Jonsson, V.D.; Rao, D.S.; O'Connell, R.M.; Baltimore, D. Oncomir miR-125b regulates hematopoiesis by targeting the gene Lin28A. Proc. Natl. Acad. Sci. USA 2012, 109, 4233-4238. [CrossRef]

112. Gururajan, M.; Haga, C.L.; Das, S.; Leu, C.-M.; Hodson, D.; Josson, S.; Turner, M.; Cooper, M.D. MicroRNA 125b inhibition of B cell differentiation in germinal centers. Int. Immunol. 2010, 22, 583-592. [CrossRef]

113. Wei, X.; Tan, C.; Tang, C.; Ren, G.; Xiang, T.; Qiu, Z.; Liu, R.; Wu, Z. Epigenetic repression of miR-132 expression by the hepatitis B virus x protein in hepatitis B virus-related hepatocellular carcinoma. Cell. Signal. 2013, 25, 1037-1043. [CrossRef] [PubMed]

114. Lagos, D.; Pollara, G.; Henderson, S.; Gratrix, F.; Fabani, M.; Milne, R.S.; Gotch, F.; Boshoff, C. MiR-132 regulates antiviral innate immunity through suppression of the p300 transcriptional co-activator. Nat. Cell Biol. 2010, 12, 513-519. [CrossRef] [PubMed]

115. Nahid, M.A.; Yao, B.; Dominguez-Gutierrez, P.R.; Kesavalu, L.; Satoh, M.; Chan, E.K. Regulation of TLR2-mediated tolerance and cross-tolerance through IRAK4 modulation by miR-132 and miR-212. J. Immunol. 2013, 190, 1250-1263. [CrossRef]

116. Mehta, A.; Zhao, J.L.; Sinha, N.; Marinov, G.K.; Mann, M.; Kowalczyk, M.S.; Galimidi, R.P.; Du, X.; Erikci, E.; Regev, A.; et al. The microRNA-132 and microRNA-212 cluster regulates hematopoietic stem cell maintenance and survival with age by buffering FOXO3 expression. Immunity 2015, 42, 1021-1032. [CrossRef] [PubMed]

117. Mehta, A.; Mann, M.; Zhao, J.L.; Marinov, G.K.; Majumdar, D.; Garcia-Flores, Y.; Du, X.; Erikci, E.; Chowdhury, K.; Baltimore, D. The microRNA-212/132 cluster regulates B cell development by targeting Sox4. J. Exp. Med. 2015, 212, 1679-1692. [CrossRef]

118. Zhao, J.; Wang, W.; Huang, Y.; Wu, J.; Chen, M.; Cui, P.; Zhang, W.; Zhang, Y. HBx elevates oncoprotein AEG-1 expression to promote cell migration by downregulating miR-375 and miR-136 in malignant hepatocytes. DNA Cell Biol. 2014, 33, 715-722. [CrossRef]

119. Zhao, L.; Zhu, J.; Zhou, H.; Zhao, Z.; Zou, Z.; Liu, X.; Lin, X.; Zhang, X.; Deng, X.; Wang, R.; et al. Identification of cellular microRNA-136 as a dual regulator of RIG-I-mediated innate immunity that antagonizes H5N1 IAV replication in A549 cells. Sci. Rep. 2015, 5, 14991. [CrossRef]

120. He, J.; Zhao, J.; Peng, X.; Shi, X.; Zong, S.; Zeng, G. Molecular mechanism of MiR-136-5p targeting NF-kB/A20 in the IL-17-mediated inflammatory response after spinal cord injury. Cell. Physiol. Biochem. 2017, 44, 1224-1241. [CrossRef] [PubMed]

121. Wang, W.; Zhao, L.J.; Tan, Y.-X.; Ren, H.; Qi, Z.-T. Identification of deregulated miRNAs and their targets in hepatitis B virus-associated hepatocellular carcinoma. World J. Gastroenterol. WJG 2012, 18, 5442. [CrossRef]

122. Wei, J.; Nduom, E.K.; Kong, L.-Y.; Hashimoto, Y.; Xu, S.; Gabrusiewicz, K.; Ling, X.; Huang, N.; Qiao, W.; Zhou, S.; et al. MiR-138 exerts anti-glioma efficacy by targeting immune checkpoints. Neuro-Oncol. 2016, 18, 639-648. [CrossRef] [PubMed] 
123. Zhao, L.; Yu, H.; Yi, S.; Peng, X.; Su, P.; Xiao, Z.; Liu, R.; Tang, A.; Li, X.; Liu, F.; et al. The tumor suppressor miR-138-5p targets PD-L1 in colorectal cancer. Oncotarget 2016, 7, 45370. [CrossRef] [PubMed]

124. Wong, C.C.L.; Wong, C.M.; Tung, E.K.K.; Au, S.L.K.; Lee, J.M.F.; Poon, R.T.P.; Man, K.; Ng, I.O.L. The microRNA miR-139 suppresses metastasis and progression of hepatocellular carcinoma by down-regulating Rho-kinase 2. Gastroenterology 2011, 140, 322-331. [CrossRef] [PubMed]

125. Qiu, G.; Lin, Y.; Zhang, H.; Wu, D. MiR-139-5p inhibits epithelial-mesenchymal transition, migration and invasion of hepatocellular carcinoma cells by targeting ZEB1 and ZEB2. Biochem. Biophys. Res. Commun. 2015, 463, 315-321. [CrossRef] [PubMed]

126. Hou, T.; Liao, J.; Zhang, C.; Sun, C.; Li, X.; Wang, G. Elevated expression of miR-146, miR-139 and miR-340 involved in regulating Th1/Th2 balance with acute exposure of fine particulate matter in mice. Int. Immunopharmacol. 2018, 54, 68-77. [CrossRef] [PubMed]

127. Bandopadhyay, M.; Banerjee, A.; Sarkar, N.; Panigrahi, R.; Datta, S.; Pal, A.; Singh, S.P.; Biswas, A.; Chakrabarti, S.; Chakravarty, R. Tumor suppressor micro RNA miR-145 and onco micro RNAs miR-21 and miR-222 expressions are differentially modulated by hepatitis B virus $X$ protein in malignant hepatocytes. BMC Cancer 2014, 14, 721. [CrossRef] [PubMed]

128. Gao, F.; Sun, X.; Wang, L.; Tang, S.; Yan, C. Downregulation of microRNA-145 caused by hepatitis B virus $\mathrm{X}$ protein promotes expression of CUL5 and contributes to pathogenesis of hepatitis B virus-associated hepatocellular carcinoma. Cell. Physiol. Biochem. 2015, 37, 1547-1559. [CrossRef]

129. Yang, X.W.; Zhang, L.j.; Huang, X.H.; Chen, L.Z.; Su, Q.; Zeng, W.T.; Li, W.; Wang, Q. MiR-145 suppresses cell invasion in hepatocellular carcinoma cells: MiR-145 targets ADAM 17. Hepatol. Res. 2014, 44, 551-559. [CrossRef]

130. Starczynowski, D.T.; Kuchenbauer, F.; Argiropoulos, B.; Sung, S.; Morin, R.; Muranyi, A.; Hirst, M.; Hogge, D.; Marra, M.; Wells, R.A.; et al. Identification of miR-145 and miR-146a as mediators of the 5q-syndrome phenotype. Nat. Med. 2010, 16, 49-58. [CrossRef]

131. Xu, X.; Fan, Z.; Kang, L.; Han, J.; Jiang, C.; Zheng, X.; Zhu, Z.; Jiao, H.; Lin, J.; Jiang, K.; et al. Hepatitis B virus $X$ protein represses miRNA-148a to enhance tumorigenesis. J. Clin. Investig. 2013, 123, 630-645. [CrossRef]

132. Zhang, J.; Zeng, C.; Xu, L.; Gong, J.; Fang, J.; Zhuang, S. MicroRNA-148a suppresses the epithelial-mesenchymal transition and metastasis of hepatoma cells by targeting Met/Snail signaling. Oncogene 2014, 33, 4069. [CrossRef] [PubMed]

133. Jung, K.H.; Zhang, J.; Zhou, C.; Shen, H.; Gagea, M.; Rodriguez-Aguayo, C.; Lopez-Berestein, G.; Sood, A.K.; Beretta, L. Differentiation therapy for hepatocellular carcinoma: Multifaceted effects of miR-148a on tumor growth and phenotype and liver fibrosis. Hepatology 2016, 63, 864-879. [CrossRef] [PubMed]

134. Liu, X.; Zhan, Z.; Xu, L.; Ma, F.; Li, D.; Guo, Z.; Li, N.; Cao, X. MicroRNA-148/152 impair innate response and antigen presentation of TLR-triggered dendritic cells by targeting CaMKII $\alpha$. J. Immunol. 2010, 185, 7244-7251. [CrossRef] [PubMed]

135. Huang, H.; Hu, M.; Li, P.; Lu, C.; Li, M. Mir-152 inhibits cell proliferation and colony formation of CD133+ liver cancer stem cells by targeting KIT. Tumor Biol. 2015, 36, 921-928. [CrossRef]

136. Heo, M.J.; Kim, Y.M.; Koo, J.H.; Yang, Y.M.; An, J.; Lee, S.-K.; Lee, S.J.; Kim, K.M.; Park, J.-W.; Kim, S.G. MicroRNA-148a dysregulation discriminates poor prognosis of hepatocellular carcinoma in association with USP4 overexpression. Oncotarget 2014, 5, 2792-2806. [CrossRef]

137. Porstner, M.; Winkelmann, R.; Daum, P.; Schmid, J.; Pracht, K.; Côrte-Real, J.; Schreiber, S.; Haftmann, C.; Brandl, A.; Mashreghi, M.F.; et al. MiR-148a promotes plasma cell differentiation and targets the germinal center transcription factors Mitf and Bach2. Eur. J. Immunol. 2015, 45, 1206-1215. [CrossRef]

138. Gonzalez-Martin, A.; Adams, B.D.; Lai, M.; Shepherd, J.; Salvador-Bernaldez, M.; Salvador, J.M.; Lu, J.; Nemazee, D.; Xiao, C. The microRNA miR-148a functions as a critical regulator of B cell tolerance and autoimmunity. Nat. Immunol. 2016, 17, 433-440. [CrossRef]

139. Huang, J.; Wang, Y.; Guo, Y.; Sun, S. Down-regulated microRNA-152 induces aberrant DNA methylation in hepatitis B virus-related hepatocellular carcinoma by targeting DNA methyltransferase 1. Hepatology 2010, 52, 60-70. [CrossRef]

140. Chen, G.; Liu, M.; Jiang, Z.; Yu, M.; Wei, S. MicroRNAs play significant roles in pathogenesis of HBV-Related diseases. J. Biomed. Sci. Eng. 2016, 9, 78. [CrossRef] 
141. Zhao, Z.; Hu, Y.; Shen, X.; Lao, Y.; Zhang, L.; Qiu, X.; Hu, J.; Gong, P.; Cui, H.; Lu, S.; et al. HBx represses RIZ1 expression by DNA methyltransferase 1 involvement in decreased miR-152 in hepatocellular carcinoma. Oncol. Rep. 2017, 37, 2811-2818. [CrossRef]

142. Wu, G.; Yu, F.; Xiao, Z.; Xu, K.; Xu, J.; Tang, W.; Wang, J.; Song, E. Hepatitis B virus X protein downregulates expression of the miR-16 family in malignant hepatocytes in vitro. Br. J. Cancer 2011, 105, 146-153. [CrossRef] [PubMed]

143. Wang, Y.; Jiang, L.; Ji, X.; Yang, B.; Zhang, Y.; Fu, X.-D. Hepatitis B viral RNA directly mediates down-regulation of the tumor suppressor microRNA miR-15a/miR-16-1 in hepatocytes. J. Biol. Chem. 2013, 288, 18484-18493. [CrossRef] [PubMed]

144. Liu, N.; Zhang, J.; Jiao, T.; Li, Z.; Peng, J.; Cui, Z.; Ye, X. Hepatitis B virus inhibits apoptosis of hepatoma cells by sponging the MicroRNA 15a/16 cluster. J. Virol. 2013, 87, 13370-13378. [CrossRef] [PubMed]

145. Schickel, R.; Boyerinas, B.; Park, S.; Peter, M. MicroRNAs: Key players in the immune system, differentiation, tumorigenesis and cell death. Oncogene 2008, 27, 5959-5974. [CrossRef]

146. Calin, G.A.; Cimmino, A.; Fabbri, M.; Ferracin, M.; Wojcik, S.E.; Shimizu, M.; Taccioli, C.; Zanesi, N.; Garzon, R.; Aqeilan, R.I.; et al. MiR-15a and miR-16-1 cluster functions in human leukemia. Proc. Natl. Acad. Sci. USA 2008, 105, 5166-5171. [CrossRef]

147. Cai, C.-K.; Zhao, G.-Y.; Tian, L.-Y.; Liu, L.; Yan, K.; Ma, Y.-L.; Ji, Z.-W.; Li, X.-X.; Han, K.; Gao, J.; et al. MiR-15a and miR-16-1 downregulate CCND1 and induce apoptosis and cell cycle arrest in osteosarcoma. Oncol. Rep. 2012, 28, 1764-1770. [CrossRef]

148. Wu, C.S.; Yen, C.J.; Chou, R.H.; Chen, J.N.; Huang, W.C.; Wu, C.Y.; Yu, Y.L. Downregulation of microRNA-15b by hepatitis $B$ virus $X$ enhances hepatocellular carcinoma proliferation via fucosyltransferase 2-induced Globo H expression. Int. J. Cancer 2014, 134, 1638-1647. [CrossRef]

149. Dai, X.; Zhang, W.; Zhang, H.; Sun, S.; Yu, H.; Guo, Y.; Kou, Z.; Zhao, G.; Du, L.; Jiang, S.; et al. Modulation of HBV replication by microRNA-15b through targeting hepatocyte nuclear factor $1 \alpha$. Nucleic Acids Res. 2014, 42, 6578-6590. [CrossRef]

150. Jing, L.; Anning, L. Role of JNK activation in apoptosis: A double-edged sword. Cell Res. 2005, 15, 36-42.

151. Liu, W.H.; Yeh, S.H.; Lu, C.C.; Yu, S.L.; Chen, H.Y.; Lin, C.Y.; Chen, D.S.; Chen, P.J. MicroRNA-18a prevents estrogen receptor- $\alpha$ expression, promoting proliferation of hepatocellular carcinoma cells. Gastroenterology 2009, 136, 683-693. [CrossRef]

152. Liu, X.; Zhang, Y.; Wang, P.; Wang, H.; Su, H.; Zhou, X.; Zhang, L. HBX protein-induced downregulation of microRNA-18a is responsible for upregulation of connective tissue growth factor in HBV infection-associated hepatocarcinoma. Med. Sci. Monit. Int. Med. J. Exp. Clin. Res. 2016, 22, 2492-2500. [CrossRef] [PubMed]

153. Wu, W.; Takanashi, M.; Borjigin, N.; Ohno, S.; Fujita, K.; Hoshino, S.; Osaka, Y.; Tsuchida, A.; Kuroda, M. MicroRNA-18a modulates STAT3 activity through negative regulation of PIAS3 during gastric adenocarcinogenesis. Br. J. Cancer 2013, 108, 653-661. [CrossRef] [PubMed]

154. Georges, S.A.; Biery, M.C.; Kim, S.-Y.; Schelter, J.M.; Guo, J.; Chang, A.N.; Jackson, A.L.; Carleton, M.O.; Linsley, P.S.; Cleary, M.A.; et al. Coordinated regulation of cell cycle transcripts by p53-Inducible microRNAs, miR-192 and miR-215. Cancer Res. 2008, 68, 10105-10112. [CrossRef] [PubMed]

155. Lian, J.; Jing, Y.; Dong, Q.; Huan, L.; Chen, D.; Bao, C.; Wang, Q.; Zhao, F.; Li, J.; Yao, M.; et al. MiR-192, a prognostic indicator, targets the SLC39A6/SNAIL pathway to reduce tumor metastasis in human hepatocellular carcinoma. Oncotarget 2016, 7, 2672-2683. [CrossRef]

156. Sun, Y.; Pan, J.; Mao, S.; Jin, J. IL-17/miR-192/IL-17Rs regulatory feedback loop facilitates multiple myeloma progression. PLoS ONE 2014, 9, e114647. [CrossRef]

157. Yip, W.K. MicroRNA Profiling of Human Hepatocytes Induced by HBx in Hepatocarcinogenesis. Ph.D. Thesis, Chinese University of Hong Kong, Hongkong, China, 2009.

158. Xu, C.; Liu, S.; Fu, H.; Li, S.; Tie, Y.; Zhu, J.; Xing, R.; Jin, Y.; Sun, Z.; Zheng, X. MicroRNA-193b regulates proliferation, migration and invasion in human hepatocellular carcinoma cells. Eur. J. Cancer 2010, 46, 2828-2836. [CrossRef]

159. Roy, S.; Benz, F.; Cardenas, D.V.; Vucur, M.; Gautheron, J.; Schneider, A.; Hellerbrand, C.; Pottier, N.; Alder, J.; Tacke, F.; et al. MiR-30c and miR-193 are a part of the TGF- $\beta$-dependent regulatory network controlling extracellular matrix genes in liver fibrosis. J. Dig. Dis. 2015, 16, 513-524. [CrossRef]

160. Hill, L.; Browne, G.; Tulchinsky, E. ZEB/miR-200 feedback loop: At the crossroads of signal transduction in cancer. Int. J. Cancer 2013, 132, 745-754. [CrossRef] 
161. Zhang, T.; Zhang, J.; Cui, M.; Liu, F.; You, X.; Du, Y.; Gao, Y.; Zhang, S.; Lu, Z.; Ye, L.; et al. Hepatitis B virus $X$ protein inhibits tumor suppressor miR-205 through inducing hypermethylation of miR-205 promoter to enhance carcinogenesis. Neoplasia 2013, 15, 1282-1291. [CrossRef]

162. Cui, M.; Wang, Y.; Sun, B.; Xiao, Z.; Ye, L.; Zhang, X. MiR-205 modulates abnormal lipid metabolism of hepatoma cells via targeting acyl-CoA synthetase long-chain family member 1 (ACSL1) mRNA. Biochem. Biophys. Res. Commun. 2014, 444, 270-275. [CrossRef]

163. Ge, W.; Yu, D.-C.; Li, Q.-G.; Chen, X.; Zhang, C.-Y.; Ding, Y.-T. Expression of serum miR-16, let-7f, and miR-21 in patients with hepatocellular carcinoma and their clinical significances. Clin. Lab. 2014, 60, 427-434. [CrossRef] [PubMed]

164. Chen, Y.; Chen, J.; Wang, H.; Shi, J.; Wu, K.; Liu, S.; Liu, Y.; Wu, J. HCV-induced miR-21 contributes to evasion of host immune system by targeting MyD88 and IRAK1. PLoS Pathog. 2013, 9, e1003248. [CrossRef] [PubMed]

165. Sheedy, F.J. Turning 21: Induction of miR-21 as a key switch in the inflammatory response. Front. Immunol. 2015, 6, 19. [CrossRef] [PubMed]

166. Murugaiyan, G.; da Cunha, A.P.; Ajay, A.K.; Joller, N.; Garo, L.P.; Kumaradevan, S.; Yosef, N.; Vaidya, V.S.; Weiner, H.L. MicroRNA-21 promotes Th17 differentiation and mediates experimental autoimmune encephalomyelitis. J. Clin. Investig. 2015, 125, 1069-1080. [CrossRef] [PubMed]

167. Liu, F.; Zhou, S.; Deng, Y.; Zhang, Z.; Zhang, E.; Wu, Z.; Huang, Z.; Chen, X. MiR-216b is involved in pathogenesis and progression of hepatocellular carcinoma through HBx-miR-216b-IGF2BP2 signaling pathway. Cell Death Dis. 2016, 6, e1670. [CrossRef]

168. Hou, B.-H.; Jian, Z.-X.; Cui, P.; Li, S.-J.; Tian, R.-Q.; Ou, J.-R. MiR-216a may inhibit pancreatic tumor growth by targeting JAK2. FEBS Lett. 2015, 589, 2224-2232. [CrossRef]

169. Felli, N.; Fontana, L.; Pelosi, E.; Botta, R.; Bonci, D.; Facchiano, F.; Liuzzi, F.; Lulli, V.; Morsilli, O.; Santoro, S.; et al. MicroRNAs 221 and 222 inhibit normal erythropoiesis and erythroleukemic cell growth via kit receptor down-modulation. Proc. Natl. Acad. Sci. USA 2005, 102, 18081-18086. [CrossRef]

170. Cao, M.; Seike, M.; Soeno, C.; Mizutani, H.; Kitamura, K.; Minegishi, Y.; Noro, R.; Yoshimura, A.; Cai, L.; Gemma, A. MiR-23a regulates TGF- $\beta$-induced epithelial-mesenchymal transition by targeting E-cadherin in lung cancer cells. Int. J. Oncol. 2012, 41, 869-875. [CrossRef] [PubMed]

171. Li, X.; Liu, X.; Xu, W.; Zhou, P.; Gao, P.; Jiang, S.; Lobie, P.E.; Zhu, T. C-MYC-regulated miR-23a/24-2/27a cluster promotes mammary carcinoma cell invasion and hepatic metastasis by targeting Sprouty2. J. Biol. Chem. 2013, 288, 18121-18133. [CrossRef]

172. Huang, S.; He, X.; Ding, J.; Liang, L.; Zhao, Y.; Zhang, Z.; Yao, X.; Pan, Z.; Zhang, P.; Li, J.; et al. Upregulation of miR-23a approximately 27a approximately 24 decreases transforming growth factor-beta-induced tumor-suppressive activities in human hepatocellular carcinoma cells. Int. J. Cancer 2008, 123, 972-978. [CrossRef]

173. Cho, S.; Wu, C.-J.; Yasuda, T.; Cruz, L.O.; Khan, A.A.; Lin, L.-L.; Nguyen, D.T.; Miller, M.; Lee, H.-M.; Kuo, M.-L.; et al. MiR-23 27 24 clusters control effector T cell differentiation and function. J. Exp. Med. 2016, 213, 235-249. [CrossRef] [PubMed]

174. Li, B.; Sun, M.; Gao, F.; Liu, W.; Yang, Y.; Liu, H.; Cheng, Y.; Liu, C.; Cai, J. Up-regulated expression of $\mathrm{miR}-23 \mathrm{a} / \mathrm{b}$ targeted the pro-apoptotic Fas in radiation-induced thymic lymphoma. Cell. Physiol. Biochem. 2013, 32, 1729-1740. [CrossRef] [PubMed]

175. Chen, L.; Zheng, J.; Zhang, Y.; Yang, L.; Wang, J.; Ni, J.; Cui, D.; Yu, C.; Cai, Z. Tumor-specific expression of microRNA-26a suppresses human hepatocellular carcinoma growth via cyclin-dependent and-independent pathways. Mol. Ther. 2011, 19, 1521-1528. [CrossRef]

176. Yang, X.; Liang, L.; Zhang, X.F.; Jia, H.L.; Qin, Y.; Zhu, X.C.; Gao, X.M.; Qiao, P.; Zheng, Y.; Sheng, Y.Y.; et al. MicroRNA-26a suppresses tumor growth and metastasis of human hepatocellular carcinoma by targeting interleukin-6-Stat3 pathway. Hepatology 2013, 58, 158-170. [CrossRef] [PubMed]

177. Ji, J.; Shi, J.; Budhu, A.; Yu, Z.; Forgues, M.; Roessler, S.; Ambs, S.; Chen, Y.; Meltzer, P.S.; Croce, C.M.; et al. MicroRNA expression, survival, and response to interferon in liver cancer. N. Engl. J. Med. 2009, 361, 1437-1447. [CrossRef] [PubMed]

178. Chen, C.-Y.A.; Chang, J.T.; Ho, Y.-F.; Shyu, A.-B. MiR-26 down-regulates TNF- $\alpha /$ NF-kB signalling and IL-6 expression by silencing HMGA1 and MALT1. Nucleic Acids Res. 2016, 44, 3772-3787. [CrossRef] [PubMed] 
179. Xiong, Y.; Fang, J.H.; Yun, J.P.; Yang, J.; Zhang, Y.; Jia, W.H.; Zhuang, S.M. Effects of MicroRNA-29 on apoptosis, tumorigenicity, and prognosis of hepatocellular carcinoma. Hepatology 2010, 51, 836-845. [CrossRef]

180. Wang, C.-M.; Wang, Y.; Fan, C.-G.; Xu, F.-F.; Sun, W.-S.; Liu, Y.-G.; Jia, J.-H. MiR-29c targets TNFAIP3, inhibits cell proliferation and induces apoptosis in hepatitis B virus-related hepatocellular carcinoma. Biochem. Biophys. Res. Commun. 2011, 411, 586-592. [CrossRef]

181. Pekarsky, Y.; Santanam, U.; Cimmino, A.; Palamarchuk, A.; Efanov, A.; Maximov, V.; Volinia, S.; Alder, H.; Liu, C.-G.; Rassenti, L.; et al. Tcl1 expression in chronic lymphocytic leukemia is regulated by miR-29 and miR-181. Cancer Res. 2006, 66, 11590-11593. [CrossRef]

182. Mott, J.L.; Kobayashi, S.; Bronk, S.F.; Gores, G.J. MiR-29 regulates Mcl-1 protein expression and apoptosis. Oncogene 2007, 26, 6133-6140. [CrossRef]

183. Ma, F.; Xu, S.; Liu, X.; Zhang, Q.; Xu, X.; Liu, M.; Hua, M.; Li, N.; Yao, H.; Cao, X. The microRNA miR-29 controls innate and adaptive immune responses to intracellular bacterial infection by targeting interferon- $\gamma$. Nat. Immunol. 2011, 12, 861-869. [CrossRef] [PubMed]

184. Fu, X.; Tan, D.; Hou, Z.; Hu, Z.; Liu, G. MiR-338-3p is down-regulated by hepatitis B virus X and inhibits cell proliferation by targeting the 3'-UTR region of cyclinD1. Int. J. Mol. Sci. 2012, 13, 8514-8539. [CrossRef] [PubMed]

185. Huang, X.H.; Wang, Q.; Chen, J.S.; Fu, X.H.; Chen, X.L.; Chen, L.Z.; Li, W.; Bi, J.; Zhang, L.J.; Fu, Q.; et al. Bead-based microarray analysis of microRNA expression in hepatocellular carcinoma: MiR-338 is downregulated. Hepatol. Res. 2009, 39, 786-794. [CrossRef] [PubMed]

186. Luo, L.; Xia, L.; Zha, B.; Zuo, C.; Deng, D.; Chen, M.; Hu, L.; He, Y.; Dai, F.; Wu, J.; et al. MiR-335-5p targeting ICAM-1 inhibits invasion and metastasis of thyroid cancer cells. Biomed. Pharmacother. 2018, 106, 983-990. [CrossRef] [PubMed]

187. Yang, P.; Li, Q.-J.; Feng, Y.; Zhang, Y.; Markowitz, G.J.; Ning, S.; Deng, Y.; Zhao, J.; Jiang, S.; Yuan, Y.; et al. TGF- $\beta$-miR-34a-CCL22 signaling-induced Treg cell recruitment promotes venous metastases of HBV-positive hepatocellular carcinoma. Cancer Cell 2012, 22, 291-303. [CrossRef]

188. Ou, Q.; Wang, G.; Li, B.; Li, W.-F. Decreased miR-34a promotes growth by regulating MAP4K4 in hepatitis B virus related hepatocellular carcinoma. Int. J. Clin. Exp. Med. 2017, 10, 2523-2531.

189. Hermeking, H. The miR-34 family in cancer and apoptosis. Cell Death Differ. 2010, 17, 193-199. [CrossRef]

190. Corney, D.C.; Flesken-Nikitin, A.; Godwin, A.K.; Wang, W.; Nikitin, A.Y. MicroRNA-34b and MicroRNA-34c are targets of p53 and cooperate in control of cell proliferation and adhesion-independent growth. Cancer Res. 2007, 67, 8433-8438. [CrossRef]

191. Sun, F.; Fu, H.; Liu, Q.; Tie, Y.; Zhu, J.; Xing, R.; Sun, Z.; Zheng, X. Downregulation of CCND1 and CDK6 by miR-34a induces cell cycle arrest. FEBS Lett. 2008, 582, 1564-1568. [CrossRef]

192. Yamakuchi, M.; Ferlito, M.; Lowenstein, C.J. MiR-34a repression of SIRT1 regulates apoptosis. Proc. Natl. Acad. Sci. USA 2008, 105, 13421-13426. [CrossRef]

193. Rao, D.S.; O'Connell, R.M.; Chaudhuri, A.A.; Garcia-Flores, Y.; Geiger, T.L.; Baltimore, D. MicroRNA-34a perturbs B lymphocyte development by repressing the forkhead box transcription factor Foxp1. Immunity 2010, 33, 48-59. [CrossRef] [PubMed]

194. Ying, J.; Yu, X.; Ma, C.; Zhang, Y.; Dong, J. MicroRNA-363-3p is downregulated in hepatocellular carcinoma and inhibits tumorigenesis by directly targeting specificity protein 1. Mol. Med. Rep. 2017, 16, 1603-1611. [CrossRef] [PubMed]

195. Arzumanyan, A.; Friedman, T.; Kotei, E.; Ng, I.O.; Lian, Z.; Feitelson, M.A. Epigenetic repression of E-cadherin expression by hepatitis B virus $x$ antigen in liver cancer. Oncogene 2012, 31, 563-572. [CrossRef] [PubMed]

196. Zhang, J.; Zhang, H.; Liu, J.; Tu, X.; Zang, Y.; Zhu, J.; Chen, J.; Dong, L.; Zhang, J. MiR-30 inhibits TGF- $\beta 1$-induced epithelial-to-mesenchymal transition in hepatocyte by targeting Snail1. Biochem. Biophys. Res. Commun. 2012, 417, 1100-1105. [CrossRef]

197. Sheng, B.; Zhao, L.; Zang, X.; Zhen, J.; Chen, W. MiR-375 ameliorates sepsis by downregulating miR-21 level via inhibiting JAK2-STAT3 signaling. Biomed. Pharmacother. 2017, 86, 254-261. [CrossRef] [PubMed]

198. Keklikoglou, I.; Koerner, C.; Schmidt, C.; Zhang, J.; Heckmann, D.; Shavinskaya, A.; Allgayer, H.; Gückel, B.; Fehm, T.; Schneeweiss, A.; et al. MicroRNA-520/373 family functions as a tumor suppressor in estrogen receptor negative breast cancer by targeting NF-kB and TGF- $\beta$ signaling pathways. Oncogene 2012, 31, 4150-4163. [CrossRef] 
199. Gao, H.; Liu, C. MiR-429 represses cell proliferation and induces apoptosis in HBV-related HCC. Biomed. Pharmacother. 2014, 68, 943-949. [CrossRef]

200. You, X.; Liu, F.; Zhang, T.; Li, Y.; Ye, L.; Zhang, X. Hepatitis B virus X protein upregulates oncogene Rab18 to result in the dysregulation of lipogenesis and proliferation of hepatoma cells. Carcinogenesis 2013, 34, 1644-1652. [CrossRef]

201. Li, J.; Du, L.; Yang, Y.; Wang, C.; Liu, H.; Wang, L.; Zhang, X.; Li, W.; Zheng, G.; Dong, Z. MiR-429 is an independent prognostic factor in colorectal cancer and exerts its anti-apoptotic function by targeting SOX2. Cancer Lett. 2013, 329, 84-90. [CrossRef]

202. Wang, Y.; Li, M.; Zang, W.; Ma, Y.; Wang, N.; Li, P.; Wang, T.; Zhao, G. MiR-429 up-regulation induces apoptosis and suppresses invasion by targeting Bcl-2 and SP-1 in esophageal carcinoma. Cell. Oncol. 2013, 36, 385-394. [CrossRef]

203. Zhang, W.; Lu, Z.; Kong, G.; Gao, Y.; Wang, T.; Wang, Q.; Cai, N.; Wang, H.; Liu, F.; Ye, L.; et al. Hepatitis B virus $\mathrm{X}$ protein accelerates hepatocarcinogenesis with partner survivin through modulating miR-520b and HBXIP. Mol. Cancer 2014, 13, 128. [CrossRef] [PubMed]

204. Hu, X.M.; Yan, X.H.; Hu, Y.W.; Huang, J.L.; Cao, S.W.; Ren, T.Y.; Tang, Y.T.; Lin, L.; Zheng, L.; Wang, Q. MiRNA-548p suppresses hepatitis B virus $X$ protein associated hepatocellular carcinoma by downregulating oncoprotein hepatitis B x-interacting protein. Hepatol. Res. 2016, 46, 804-815. [CrossRef] [PubMed]

205. Li, Y.; Xie, J.; Xu, X.; Wang, J.; Ao, F.; Wan, Y.; Zhu, Y. MicroRNA-548 down-regulates host antiviral response via direct targeting of IFN- $\lambda 1$. Protein Cell 2013, 4, 130-141. [CrossRef] [PubMed]

206. Chen, W.-S.; Yen, C.-J.; Chen, Y.-J.; Chen, J.-Y.; Wang, L.-Y.; Chiu, S.-J.; Shih, W.-L.; Ho, C.-Y.; Wei, T.-T.; Pan, H.-L.; et al. MiRNA-7/21/107 contribute to HBx-induced hepatocellular carcinoma progression through suppression of maspin. Oncotarget 2015, 6, 25962-25974. [CrossRef]

207. Zhang, J.-J.; Wang, C.-Y.; Hua, L.; Yao, K.-H.; Chen, J.-T.; Hu, J.-H. MiR-107 promotes hepatocellular carcinoma cell proliferation by targeting Axin2. Int. J. Clin. Exp. Pathol. 2015, 8, 5168-5174. [PubMed]

208. Takahashi, Y.; Forrest, A.R.; Maeno, E.; Hashimoto, T.; Daub, C.O.; Yasuda, J. MiR-107 and MiR-185 can induce cell cycle arrest in human non small cell lung cancer cell lines. PLoS ONE 2009, 4, e6677. [CrossRef] [PubMed]

209. Feng, L.; Xie, Y.; Zhang, H.; Wu, Y. MiR-107 targets cyclin-dependent kinase 6 expression, induces cell cycle G1 arrest and inhibits invasion in gastric cancer cells. Med. Oncol. 2012, 29, 856-863. [CrossRef]

210. Mosca, N.; Castiello, F.; Coppola, N.; Trotta, M.C.; Sagnelli, C.; Pisaturo, M.; Sagnelli, E.; Russo, A.; Potenza, N. Functional interplay between hepatitis B virus $X$ protein and human miR-125a in HBV infection. Biochem. Biophys. Res. Commun. 2014, 449, 141-145. [CrossRef]

211. Potenza, N.; Papa, U.; Mosca, N.; Zerbini, F.; Nobile, V.; Russo, A. Human microRNA hsa-miR-125a-5p interferes with expression of hepatitis B virus surface antigen. Nucleic Acids Res. 2011, 39, 5157-5163. [CrossRef]

212. Zhang, X.; Liu, S.; Hu, T.; Liu, S.; He, Y.; Sun, S. Up-regulated microRNA-143 transcribed by nuclear factor kappa B enhances hepatocarcinoma metastasis by repressing fibronectin expression. Hepatology 2009, 50, 490-499. [CrossRef]

213. Hou, Y.; Feng, H.; Jiao, J.; Qian, L.; Sun, B.; Chen, P.; Li, Q.; Liang, Z. Mechanism of miR-143-3p inhibiting proliferation, migration and invasion of osteosarcoma cells by targeting MAPK7. Artif. Cells Nanomed. Biotechnol. 2019, 47, 2065-2071. [CrossRef] [PubMed]

214. Li, J.-F.; Dai, X.-P.; Zhang, W.; Sun, S.-H.; Zeng, Y.; Zhao, G.-Y.; Kou, Z.-H.; Guo, Y.; Yu, H.; Du, L.-Y.; et al. Upregulation of microRNA-146a by hepatitis B virus $\mathrm{X}$ protein contributes to hepatitis development by downregulating complement factor H. MBio 2015, 6. [CrossRef] [PubMed]

215. Hou, Z.H.; Han, Q.J.; Zhang, C.; Tian, Z.G.; Zhang, J. MiR146a impairs the IFN-induced anti-HBV immune response by downregulating STAT1 in hepatocytes. Liver Int. 2014, 34, 58-68. [CrossRef] [PubMed]

216. Gui, J.; Tian, Y.; Wen, X.; Zhang, W.; Zhang, P.; Gao, J.; Run, W.; Tian, L.; Jia, X.; Gao, Y. Serum microRNA characterization identifies miR-885-5p as a potential marker for detecting liver pathologies. Clin. Sci. 2011, 120, 183-193. [CrossRef]

217. O'neill, L.A.; Sheedy, F.J.; McCoy, C.E. MicroRNAs: The fine-tuners of Toll-like receptor signalling. Nat. Rev. Immunol. 2011, 11, 163-175. [CrossRef] 
218. Taganov, K.D.; Boldin, M.P.; Chang, K.-J.; Baltimore, D. NF-kB-dependent induction of microRNA miR-146, an inhibitor targeted to signaling proteins of innate immune responses. Proc. Natl. Acad. Sci. USA 2006, 103, 12481-12486. [CrossRef]

219. Zhao, J.L.; Rao, D.S.; Boldin, M.P.; Taganov, K.D.; O'Connell, R.M.; Baltimore, D. NF-kB dysregulation in microRNA-146a-deficient mice drives the development of myeloid malignancies. Proc. Natl. Acad. Sci. USA 2011, 108, 9184-9189. [CrossRef]

220. Zhao, J.L.; Rao, D.S.; O'Connell, R.M.; Garcia-Flores, Y.; Baltimore, D. MicroRNA-146a acts as a guardian of the quality and longevity of hematopoietic stem cells in mice. Elife 2013, 2, e00537. [CrossRef]

221. Huffaker, T.B.; Hu, R.; Runtsch, M.C.; Bake, E.; Chen, X.; Zhao, J.; Round, J.L.; Baltimore, D.; O'Connell, R.M. Epistasis between microRNAs 155 and 146a during T cell-mediated antitumor immunity. Cell Rep. 2012, 2, 1697-1709. [CrossRef]

222. Lu, L.-F.; Boldin, M.P.; Chaudhry, A.; Lin, L.-L.; Taganov, K.D.; Hanada, T.; Yoshimura, A.; Baltimore, D.; Rudensky, A.Y. Function of miR-146a in controlling Treg cell-mediated regulation of Th1 responses. Cell 2010, 142, 914-929. [CrossRef]

223. Boldin, M.P.; Taganov, K.D.; Rao, D.S.; Yang, L.; Zhao, J.L.; Kalwani, M.; Garcia-Flores, Y.; Luong, M.; Devrekanli, A.; $\mathrm{Xu}$, J.; et al. MiR-146a is a significant brake on autoimmunity, myeloproliferation, and cancer in mice. J. Exp. Med. 2011, 208, 1189-1201. [CrossRef] [PubMed]

224. Xie, Q.; Chen, X.; Lu, F.; Zhang, T.; Hao, M.; Wang, Y.; Zhao, J.; McCrae, M.A.; Zhuang, H. Aberrant expression of microRNA 155 may accelerate cell proliferation by targeting sex-determining region $\mathrm{Y}$ box 6 in hepatocellular carcinoma. Cancer 2012, 118, 2431-2442. [CrossRef] [PubMed]

225. Song, X.; Tan, S.; Wu, Z.; Xu, L.; Wang, Z.; Xu, Y.; Wang, T.; Gao, C.; Gong, Y.; Liang, X.; et al. HBV suppresses ZHX2 expression to promote proliferation of HCC through miR-155 activation. Int. J. Cancer 2018, 143, 3120-3130. [CrossRef]

226. Fu, X.; Wen, H.; Jing, L.; Yang, Y.; Wang, W.; Liang, X.; Nan, K.; Yao, Y.; Tian, T. Micro RNA-155-5p promotes hepatocellular carcinoma progression by suppressing PTEN through the PI 3K/Akt pathway. Cancer Sci. 2017, 108, 620-631. [CrossRef]

227. Kohlhaas, S.; Garden, O.A.; Scudamore, C.; Turner, M.; Okkenhaug, K.; Vigorito, E. Cutting edge: The Foxp3 target miR-155 contributes to the development of regulatory T cells. J. Immunol. 2009, 182, 2578-2582. [CrossRef] [PubMed]

228. Rodriguez, A.; Vigorito, E.; Clare, S.; Warren, M.V.; Couttet, P.; Soond, D.R.; Van Dongen, S.; Grocock, R.J.; Das, P.P.; Miska, E.A.; et al. Requirement of bic/microRNA-155 for normal immune function. Science 2007, 316, 608-611. [CrossRef] [PubMed]

229. Thai, T.-H.; Calado, D.P.; Casola, S.; Ansel, K.M.; Xiao, C.; Xue, Y.; Murphy, A.; Frendewey, D.; Valenzuela, D.; Kutok, J.L.; et al. Regulation of the germinal center response by microRNA-155. Science 2007, 316, 604-608. [CrossRef]

230. Curtis, A.M.; Fagundes, C.T.; Yang, G.; Palsson-McDermott, E.M.; Wochal, P.; McGettrick, A.F.; Foley, N.H.; Early, J.O.; Chen, L.; Zhang, H. Circadian control of innate immunity in macrophages by miR-155 targeting Bmal1. Proc. Natl. Acad. Sci. USA 2015, 112, 7231-7236. [CrossRef]

231. O'Connell, R.M.; Chaudhuri, A.A.; Rao, D.S.; Baltimore, D. Inositol phosphatase SHIP1 is a primary target of miR-155. Proc. Natl. Acad. Sci. USA 2009, 106, 7113-7118. [CrossRef]

232. O'Connell, R.M.; Taganov, K.D.; Boldin, M.P.; Cheng, G.; Baltimore, D. MicroRNA-155 is induced during the macrophage inflammatory response. Proc. Natl. Acad. Sci. USA 2007, 104, 1604-1609. [CrossRef]

233. Wang, L.; Zhang, H.; Rodriguez, S.; Cao, L.; Parish, J.; Mumaw, C.; Zollman, A.; Kamoka, M.M.; Mu, J.; Chen, D.Z.; et al. Notch-dependent repression of miR-155 in the bone marrow niche regulates hematopoiesis in an NF-kB-dependent manner. Cell Stem Cell 2014, 15, 51-65. [CrossRef] [PubMed]

234. O'Connell, R.M.; Rao, D.S.; Chaudhuri, A.A.; Boldin, M.P.; Taganov, K.D.; Nicoll, J.; Paquette, R.L.; Baltimore, D. Sustained expression of microRNA-155 in hematopoietic stem cells causes a myeloproliferative disorder. J. Exp. Med. 2008, 205, 585-594. [CrossRef] [PubMed]

235. Gerloff, D.; Grundler, R.; Wurm, A.; Bräuer-Hartmann, D.; Katzerke, C.; Hartmann, J.; Madan, V.; Müller-Tidow, C.; Duyster, J.; Tenen, D.G.; et al. NF-kB/STAT5/miR-155 network targets PU. 1 in FLT3-ITD-driven acute myeloid leukemia. Leukemia 2015, 29, 535-547. [CrossRef] 
236. Teng, G.; Hakimpour, P.; Landgraf, P.; Rice, A.; Tuschl, T.; Casellas, R.; Papavasiliou, F.N. MicroRNA-155 is a negative regulator of activation-induced cytidine deaminase. Immunity 2008, 28, 621-629. [CrossRef] [PubMed]

237. Hu, R.; Huffaker, T.B.; Kagele, D.A.; Runtsch, M.C.; Bake, E.; Chaudhuri, A.A.; Round, J.L.; O'Connell, R.M. MicroRNA-155 confers encephalogenic potential to Th17 cells by promoting effector gene expression. J. Immunol. 2013, 190, 5972-5980. [CrossRef] [PubMed]

238. Yao, R.; Ma, Y.-L.; Liang, W.; Li, H.-H.; Ma, Z.-J.; Yu, X.; Liao, Y.-H. MicroRNA-155 modulates Treg and Th17 cells differentiation and Th17 cell function by targeting SOCS1. PLoS ONE 2012, 7, e46082. [CrossRef] [PubMed]

239. Jung, Y.J.; Kim, J.W.; Park, S.J.; Min, B.Y.; Jang, E.S.; Kim, N.Y.; Jeong, S.H.; Shin, C.M.; Lee, S.H.; Park, Y.S.; et al. C-Myc-mediated overexpression of miR-17-92 suppresses replication of hepatitis B virus in human hepatoma cells. J. Med Virol. 2013, 85, 969-978. [CrossRef]

240. Aguda, B.D.; Kim, Y.; Piper-Hunter, M.G.; Friedman, A.; Marsh, C.B. MicroRNA regulation of a cancer network: Consequences of the feedback loops involving miR-17-92, E2F, and Myc. Proc. Natl. Acad. Sci. USA 2008, 105, 19678-19683. [CrossRef]

241. Connolly, E.; Melegari, M.; Landgraf, P.; Tchaikovskaya, T.; Tennant, B.C.; Slagle, B.L.; Rogler, L.E.; Zavolan, M.; Tuschl, T.; Rogler, C.E. Elevated expression of the miR-17-92 polycistron and miR-21 in hepadnavirus-associated hepatocellular carcinoma contributes to the malignant phenotype. Am. J. Pathol. 2008, 173, 856-864. [CrossRef]

242. Kang, S.G.; Liu, W.-H.; Lu, P.; Jin, H.Y.; Lim, H.W.; Shepherd, J.; Fremgen, D.; Verdin, E.; Oldstone, M.B.; Qi, H.; et al. MicroRNAs of the miR-17 92 family are critical regulators of T FH differentiation. Nat. Immunol. 2013, 14, 849-857. [CrossRef]

243. Ventura, A.; Young, A.G.; Winslow, M.M.; Lintault, L.; Meissner, A.; Erkeland, S.J.; Newman, J.; Bronson, R.T.; Crowley, D.; Stone, J.R.; et al. Targeted deletion reveals essential and overlapping functions of the miR-17 92 family of miRNA clusters. Cell 2008, 132, 875-886. [CrossRef] [PubMed]

244. Blevins, R.; Bruno, L.; Carroll, T.; Elliott, J.; Marcais, A.; Loh, C.; Hertweck, A.; Krek, A.; Rajewsky, N.; Chen, C.-Z; et al. MicroRNAs regulate cell-to-cell variability of endogenous target gene expression in developing mouse thymocytes. PLoS Genet. 2015, 11, e1005020. [CrossRef] [PubMed]

245. Jiang, S.; Li, C.; Olive, V.; Lykken, E.; Feng, F.; Sevilla, J.; Wan, Y.; He, L.; Li, Q.-J. Molecular dissection of the miR-17-92 cluster's critical dual roles in promoting Th1 responses and preventing inducible Treg differentiation. Blood J. Am. Soc. Hematol. 2011, 118, 5487-5497. [CrossRef] [PubMed]

246. Zou, C.; Chen, J.; Chen, K.; Wang, S.; Cao, Y.; Zhang, J.; Sheng, Y.; Huang, A.; Tang, H. Functional analysis of miR-181a and Fas involved in hepatitis B virus-related hepatocellular carcinoma pathogenesis. Exp. Cell Res. 2015, 331, 352-361. [CrossRef]

247. Zou, C.; Li, Y.; Cao, Y.; Zhang, J.; Jiang, J.; Sheng, Y.; Wang, S.; Huang, A.; Tang, H. Up-regulated MicroRNA-181a induces carcinogenesis in Hepatitis B virus-related hepatocellular carcinoma by targeting E2F5. BMC Cancer 2014, 14, 97. [CrossRef]

248. De Yébenes, V.G.; Belver, L.; Pisano, D.G.; González, S.; Villasante, A.; Croce, C.; He, L.; Ramiro, A.R. MiR-181b negatively regulates activation-induced cytidine deaminase in B cells. J. Exp. Med. 2008, 205, 2199-2206. [CrossRef]

249. Li, Q.-J.; Chau, J.; Ebert, P.J.; Sylvester, G.; Min, H.; Liu, G.; Braich, R.; Manoharan, M.; Soutschek, J.; Skare, P.; et al. MiR-181a is an intrinsic modulator of T cell sensitivity and selection. Cell 2007, 129, 147-161. [CrossRef]

250. Cichocki, F.; Felices, M.; McCullar, V.; Presnell, S.R.; Al-Attar, A.; Lutz, C.T.; Miller, J.S. Cutting edge: MicroRNA-181 promotes human NK cell development by regulating Notch signaling. J. Immunol. 2011, 187, 6171-6175. [CrossRef]

251. Lodish, H.F.; Zhou, B.; Liu, G.; Chen, C.-Z. Micromanagement of the immune system by microRNAs. Nat. Rev. Immunol. 2008, 8, 120-130. [CrossRef]

252. Wu, A.; Chen, H.; Xu, C.; Zhou, J.; Chen, S.; Shi, Y.; Xu, J.; Gan, J.; Zhang, J. MiR-203a is involved in HBx-induced inflammation by targeting Rap1a. Exp. Cell Res. 2016, 349, 191-197. [CrossRef]

253. Qiu, X.; Dong, S.; Qiao, F.; Lu, S.; Song, Y.; Lao, Y.; Li, Y.; Zeng, T.; Hu, J.; Zhang, L.; et al. HBx-mediated miR-21 upregulation represses tumor-suppressor function of PDCD4 in hepatocellular carcinoma. Oncogene 2013, 32, 3296-3305. [CrossRef] [PubMed] 
254. Momeni, M.; Hassanshahi, G.; Arababadi, M.K.; Kennedy, D. Ectopic expression of micro-RNA-1, 21 and 125a in peripheral blood immune cells is associated with chronic HBV infection. Mol. Biol. Rep. 2014, 41, 4833-4837. [CrossRef] [PubMed]

255. Damania, P.; Sen, B.; Dar, S.B.; Kumar, S.; Kumari, A.; Gupta, E.; Sarin, S.K.; Venugopal, S.K. Hepatitis B virus induces cell proliferation via HBx-induced microRNA-21 in hepatocellular carcinoma by targeting programmed cell death protein4 (PDCD4) and phosphatase and tensin homologue (PTEN). PLoS ONE 2014, 9, e91745. [CrossRef] [PubMed]

256. Liu, C.; Yu, J.; Yu, S.; Lavker, R.M.; Cai, L.; Liu, W.; Yang, K.; He, X.; Chen, S. MicroRNA-21 acts as an oncomir through multiple targets in human hepatocellular carcinoma. J. Hepatol. 2010, 53, 98-107. [CrossRef]

257. Trung, N.T.; Duong, D.C.; Van Tong, H.; Hien, T.T.T.; Hoan, P.Q.; Bang, M.H.; Binh, M.T.; Ky, T.D.; Tung, N.L.; Thinh, N.T.; et al. Optimisation of quantitative miRNA panels to consolidate the diagnostic surveillance of HBV-related hepatocellular carcinoma. PLOS ONE 2018, 13, e0196081. [CrossRef]

258. Liu, F.; You, X.; Chi, X.; Wang, T.; Ye, L.; Niu, J.; Zhang, X. Hepatitis B virus X protein mutant $H B x \Delta 127$ promotes proliferation of hepatoma cells through up-regulating miR-215 targeting PTPRT. Biochem. Biophys. Res. Commun. 2014, 444, 128-134. [CrossRef]

259. Chen, J.-J.; Tang, Y.-S.; Huang, S.-F.; Ai, J.-G.; Wang, H.-X.; Zhang, L.-P. HBx protein-induced upregulation of microRNA-221 promotes aberrant proliferation in HBV-related hepatocellular carcinoma by targeting estrogen receptor- $\alpha$. Oncol. Rep. 2015, 33, 792-798. [CrossRef]

260. Rong, M.; Chen, G.; Dang, Y. Increased miR-221 expression in hepatocellular carcinoma tissues and its role in enhancing cell growth and inhibiting apoptosis in vitro. BMC Cancer 2013, 13, 21. [CrossRef]

261. Yang, Y.-F.; Wang, F.; Xiao, J.-J.; Song, Y.; Zhao, Y.-Y.; Cao, Y.; Bei, Y.-H.; Yang, C.-Q. MiR-222 overexpression promotes proliferation of human hepatocellular carcinoma HepG2 cells by downregulating p27. Int. J. Clin. Exp. Med. 2014, 7, 893.

262. Huang, S.; Zhou, D.; Li, Y.X.; Ming, Z.Y.; Li, K.Z.; Wu, G.B.; Chen, C.; Zhao, Y.N. In vivo and in vitro effects of microRNA-221 on hepatocellular carcinoma development and progression through the JAK-STAT3 signaling pathway by targeting SOCS3. J. Cell. Physiol. 2019, 234, 3500-3514. [CrossRef]

263. Fornari, F.; Gramantieri, L.; Ferracin, M.; Veronese, A.; Sabbioni, S.; Calin, G.A.; Grazi, G.L.; Giovannini, C.; Croce, C.M.; Bolondi, L.; et al. MiR-221 controls CDKN1C/p57 and CDKN1B/p27 expression in human hepatocellular carcinoma. Oncogene 2008, 27, 5651-5661. [CrossRef] [PubMed]

264. Mayoral, R.J.; Pipkin, M.E.; Pachkov, M.; Van Nimwegen, E.; Rao, A.; Monticelli, S. MicroRNA-221-222 regulate the cell cycle in mast cells. J. Immunol. 2009, 182, 433-445. [CrossRef]

265. Wong, Q.W.; Ching, A.K.; Chan, A.W.; Choy, K.-W.; To, K.-F.; Lai, P.B.; Wong, N. MiR-222 overexpression confers cell migratory advantages in hepatocellular carcinoma through enhancing AKT signaling. Clin. Cancer Res. 2010, 16, 867-875. [CrossRef] [PubMed]

266. Gramantieri, L.; Fornari, F.; Callegari, E.; Sabbioni, S.; Lanza, G.; Croce, C.M.; Bolondi, L.; Negrini, M. MicroRNA involvement in hepatocellular carcinoma. J. Cell. Mol. Med. 2008, 12, 2189-2204. [CrossRef] [PubMed]

267. Garofalo, M.; Di Leva, G.; Romano, G.; Nuovo, G.; Suh, S.-S.; Ngankeu, A.; Taccioli, C.; Pichiorri, F.; Alder, H.; Secchiero, P.; et al. MiR-221\&222 regulate TRAIL resistance and enhance tumorigenicity through PTEN and TIMP3 downregulation. Cancer Cell 2009, 16, 498-509. [PubMed]

268. Wang, Y.; Lee, A.T.; Ma, J.Z.; Wang, J.; Ren, J.; Yang, Y.; Tantoso, E.; Li, K.-B.; Ooi, L.L.J.; Tan, P.; et al. Profiling microRNA expression in hepatocellular carcinoma reveals microRNA-224 up-regulation and apoptosis inhibitor-5 as a microRNA-224-specific target. J. Biol. Chem. 2008, 283, 13205-13215. [CrossRef]

269. Lan, S.H.; Wu, S.Y.; Zuchini, R.; Lin, X.Z.; Su, I.J.; Tsai, T.F.; Lin, Y.J.; Wu, C.T.; Liu, H.S. Autophagy suppresses tumorigenesis of hepatitis $B$ virus-associated hepatocellular carcinoma through degradation of microRNA-224. Hepatology 2014, 59, 505-517. [CrossRef]

270. Scisciani, C.; Vossio, S.; Guerrieri, F.; Schinzari, V.; De Iaco, R.; De Meo, P.D.O.; Cervello, M.; Montalto, G.; Pollicino, T.; Raimondo, G.; et al. Transcriptional regulation of miR-224 upregulated in human HCCs by NFKB inflammatory pathways. J. Hepatol. 2012, 56, 855-861. [CrossRef]

271. Wang, Y.; Ren, J.; Gao, Y.; Ma, J.Z.; Toh, H.C.; Chow, P.; Chung, A.Y.; Ooi, L.L.; Lee, C.G. MicroRNA-224 targets SMAD family member 4 to promote cell proliferation and negatively influence patient survival. PLoS ONE 2013, 8, e68744. [CrossRef] 
272. Zhang, H.; Yan, X.-L.; Guo, X.-X.; Shi, M.-J.; Lu, Y.-Y.; Zhou, Q.-M.; Chen, Q.-L.; Hu, Y.-Y.; Xu, L.-M.; Huang, S.; et al. MiR-27a as a predictor for the activation of hepatic stellate cells and hepatitis B virus-induced liver cirrhosis. Oncotarget 2017, 9, 1075-1090. [CrossRef]

273. Wu, X.-J.; Li, Y.; Liu, D.; Zhao, L.-D.; Bai, B.; Xue, M.-H. MiR-27a as an oncogenic microRNA of hepatitis B virus-related hepatocellular carcinoma. Asian Pac. J. Cancer Prev. 2013, 14, 885-889. [CrossRef]

274. Pua, H.H.; Steiner, D.F.; Patel, S.; Gonzalez, J.R.; Ortiz-Carpena, J.F.; Kageyama, R.; Chiou, N.-T.; Gallman, A.; De Kouchkovsky, D.; Jeker, L.T.; et al. MicroRNAs 24 and 27 suppress allergic inflammation and target a network of regulators of $\mathrm{T}$ helper 2 cell-associated cytokine production. Immunity 2016, 44, 821-832. [CrossRef] [PubMed]

275. Yao, F.; Yu, Y.; Feng, L.; Li, J.; Zhang, M.; Lan, X.; Yan, X.; Liu, Y.; Guan, F.; Zhang, M.; et al. Adipogenic miR-27a in adipose tissue upregulates macrophage activation via inhibiting PPAR $\gamma$ of insulin resistance induced by high-fat diet-associated obesity. Exp. Cell Res. 2017, 355, 105-112. [CrossRef] [PubMed]

276. Kong, G.; Zhang, J.; Zhang, S.; Shan, C.; Ye, L.; Zhang, X. Upregulated microRNA-29a by hepatitis B virus X protein enhances hepatoma cell migration by targeting PTEN in cell culture model. PLoS ONE 2011, 6, e19518. [CrossRef]

277. Liston, A.; Papadopoulou, A.S.; Danso-Abeam, D.; Dooley, J. MicroRNA-29 in the adaptive immune system: Setting the threshold. Cell. Mol. Life Sci. 2012, 69, 3533-3541. [CrossRef] [PubMed]

278. Han, Y.-C.; Park, C.Y.; Bhagat, G.; Zhang, J.; Wang, Y.; Fan, J.-B.; Liu, M.; Zou, Y.; Weissman, I.L.; $\mathrm{Gu}, \mathrm{H}$. MicroRNA-29a induces aberrant self-renewal capacity in hematopoietic progenitors, biased myeloid development, and acute myeloid leukemia. J. Exp. Med. 2010, 207, 475-489. [CrossRef]

279. Gong, J.; Liu, R.; Zhuang, R.; Zhang, Y.; Fang, L.; Xu, Z.; Jin, L.; Wang, T.; Song, C.; Yang, K.; et al. MiR-30c-1* promotes natural killer cell cytotoxicity against human hepatoma cells by targeting the transcription factor $\mathrm{HMBOX}_{1}$. Cancer Sci. 2012, 103, 645-652. [CrossRef]

280. Calame, K. Activation-dependent induction of Blimp-1. Curr. Opin. Immunol. 2008, 20, 259-264. [CrossRef]

281. Li, J.; Donath, S.; Li, Y.; Qin, D.; Prabhakar, B.S.; Li, P. MiR-30 regulates mitochondrial fission through targeting p53 and the dynamin-related protein-1 pathway. PLoS Genet. 2010, 6, e1000795. [CrossRef]

282. Cao, Y.; Chen, J.; Wang, D.; Peng, H.; Tan, X.; Xiong, D.; Huang, A.; Tang, H. Upregulated in Hepatitis $B$ virus-associated hepatocellular carcinoma cells, miR-331-3p promotes proliferation of hepatocellular carcinoma cells by targeting ING5. Oncotarget 2015, 6, 38093. [CrossRef]

283. Jin, W.; Zhong, N.; Wang, L.; Yu, J.; Yin, F.; Zhang, K. MiR-331-3p inhibition of the hepatocellular carcinoma (HCC) Bel-7402 cell line by down-regulation of E2F1. J. Nanosci. Nanotechnol. 2019, 19, 5476-5482. [CrossRef] [PubMed]

284. Zhao, Q.; Li, T.; Qi, J.; Liu, J.; Qin, C. The miR-545/374a cluster encoded in the Ftx lncRNA is overexpressed in HBV-related hepatocellular carcinoma and promotes tumorigenesis and tumor progression. PLoS ONE 2014, 9, e109782. [CrossRef] [PubMed]

285. Zhang, B.; Han, S.; Feng, B.; Chu, X.; Chen, L.; Wang, R. Hepatitis B virus X protein-mediated non-coding RNA aberrations in the development of human hepatocellular carcinoma. Exp. Mol. Med. 2017, 49, e293. [CrossRef] [PubMed]

286. Qian, D.; Chen, K.; Deng, H.; Rao, H.; Huang, H.; Liao, Y.; Sun, X.; Lu, S.; Yuan, Z.; Xie, D.; et al. MicroRNA-374b suppresses proliferation and promotes apoptosis in T-cell lymphoblastic lymphoma by repressing AKT1 and Wnt-16. Clin. Cancer Res. 2015, 21, 4881-4891. [CrossRef] [PubMed]

287. Yang, L.; Ma, Z.; Wang, D.; Zhao, W.; Chen, L.; Wang, G. MicroRNA-602 regulating tumor suppressive gene RASSF1A is over-expressed in hepatitis B virus-infected liver and hepatocellular carcinoma. Cancer Biol. Ther. 2010, 9, 803-808. [CrossRef] [PubMed]

288. Chen, Y.-J.; Chien, P.-H.; Chen, W.-S.; Chien, Y.-F.; Hsu, Y.-Y.; Wang, L.-Y.; Chen, J.-Y.; Lin, C.-W.; Huang, T.-C.; $\mathrm{Yu}, \mathrm{Y}$.-L.; et al. Hepatitis B virus-encoded X protein downregulates EGFR expression via inducing microRNA-7 in hepatocellular carcinoma cells. Evid. Based Complement. Altern. Med. 2013, 2013, 682380. [CrossRef]

289. Zhang, X.; Hu, S.; Zhang, X.; Wang, L.; Zhang, X.; Yan, B.; Zhao, J.; Yang, A.; Zhang, R. MicroRNA-7 arrests cell cycle in G1 phase by directly targeting CCNE1 in human hepatocellular carcinoma cells. Biochem. Biophys. Res. Commun. 2014, 443, 1078-1084. [CrossRef]

290. Nguyen, H.T.T.; Dalmasso, G.; Yan, Y.; Laroui, H.; Dahan, S.; Mayer, L.; Sitaraman, S.V.; Merlin, D. MicroRNA-7 modulates CD98 expression during intestinal epithelial cell differentiation. J. Biol. Chem. 2010, 285, 1479-1489. [CrossRef] 
291. Wang, Y.; Wang, Q.; Song, J. Inhibition of autophagy potentiates the proliferation inhibition activity of microRNA-7 in human hepatocellular carcinoma cells. Oncol. Lett. 2017, 14, 3566-3572. [CrossRef]

292. Midgley, A.; Bowen, T.; Phillips, A.; Steadman, R. MicroRNA-7 inhibition rescues age-associated loss of EGF receptor and hyaluronan (HA)-dependent differentiation in fibroblasts. Aging Cell 2014, 13, 235-244. [CrossRef]

293. Bushati, N.; Cohen, S.M. MicroRNA functions. Annu. Rev. Cell Dev. Biol. 2007, 23, 175-205. [CrossRef] [PubMed]

294. Mehta, A.; Baltimore, D. MicroRNAs as regulatory elements in immune system logic. Nat. Rev. Immunol. 2016, 16, 279. [CrossRef] [PubMed]

295. Velu, C.S.; Baktula, A.M.; Grimes, H.L. Gfi1 regulates miR-21 and miR-196b to control myelopoiesis. Blood J. Am. Soc. Hematol. 2009, 113, 4720-4728. [CrossRef]

296. Gulyaeva, L.F.; Kushlinskiy, N.E. Regulatory mechanisms of microRNA expression. J. Transl. Med. 2016, 14, 143. [CrossRef]

297. Johnnidis, J.B.; Harris, M.H.; Wheeler, R.T.; Stehling-Sun, S.; Lam, M.H.; Kirak, O.; Brummelkamp, T.R.; Fleming, M.D.; Camargo, F.D. Regulation of progenitor cell proliferation and granulocyte function by microRNA-223. Nature 2008, 451, 1125-1129. [CrossRef] [PubMed]

298. Häger, M.; Pedersen, C.C.; Larsen, M.T.; Andersen, M.K.; Hother, C.; Grønbæk, K.; Jarmer, H.; Borregaard, N.; Cowland, J.B. MicroRNA-130a-mediated down-regulation of Smad4 contributes to reduced sensitivity to TGF- $\beta 1$ stimulation in granulocytic precursors. Blood J. Am. Soc. Hematol. 2011, 118, 6649-6659. [CrossRef]

299. Fontana, L.; Pelosi, E.; Greco, P.; Racanicchi, S.; Testa, U.; Liuzzi, F.; Croce, C.M.; Brunetti, E.; Grignani, F.; Peschle, C. MicroRNAs 17-5p-20a-106a control monocytopoiesis through AML1 targeting and M-CSF receptor upregulation. Nat. Cell Biol. 2007, 9, 775-787. [CrossRef]

300. Fazi, F.; Rosa, A.; Fatica, A.; Gelmetti, V.; De Marchis, M.L.; Nervi, C.; Bozzoni, I. A minicircuitry comprised of microRNA-223 and transcription factors NFI-A and C/EBP $\alpha$ regulates human granulopoiesis. Cell 2005, 123, 819-831. [CrossRef]

301. Sheedy, F.J.; Palsson-McDermott, E.; Hennessy, E.J.; Martin, C.; O’leary, J.J.; Ruan, Q.; Johnson, D.S.; Chen, Y.; O'neill, L.A. Negative regulation of TLR4 via targeting of the proinflammatory tumor suppressor PDCD4 by the microRNA miR-21. Nat. Immunol. 2010, 11, 141-147. [CrossRef]

302. Hou, J.; Wang, P.; Lin, L.; Liu, X.; Ma, F.; An, H.; Wang, Z.; Cao, X. MicroRNA-146a feedback inhibits RIG-I-dependent Type I IFN production in macrophages by targeting TRAF6, IRAK1, and IRAK2. J. Immunol. 2009, 183, 2150-2158. [CrossRef]

303. Androulidaki, A.; Iliopoulos, D.; Arranz, A.; Doxaki, C.; Schworer, S.; Zacharioudaki, V.; Margioris, A.N.; Tsichlis, P.N.; Tsatsanis, C. The kinase Akt1 controls macrophage response to lipopolysaccharide by regulating microRNAs. Immunity 2009, 31, 220-231. [CrossRef] [PubMed]

304. Ceppi, M.; Pereira, P.M.; Dunand-Sauthier, I.; Barras, E.; Reith, W.; Santos, M.A.; Pierre, P. MicroRNA-155 modulates the interleukin-1 signaling pathway in activated human monocyte-derived dendritic cells. Proc. Natl. Acad. Sci. USA 2009, 106, 2735-2740. [CrossRef]

305. Hashimi, S.T.; Fulcher, J.A.; Chang, M.H.; Gov, L.; Wang, S.; Lee, B. MicroRNA profiling identifies miR-34a and miR-21 and their target genes JAG1 and WNT1 in the coordinate regulation of dendritic cell differentiation. Blood 2009, 114, 404-414. [CrossRef] [PubMed]

306. Stern-Ginossar, N.; Gur, C.; Biton, M.; Horwitz, E.; Elboim, M.; Stanietsky, N.; Mandelboim, M.; Mandelboim, O. Human microRNAs regulate stress-induced immune responses mediated by the receptor NKG2D. Nat. Immunol. 2008, 9, 1065. [CrossRef]

307. Stern-Ginossar, N.; Elefant, N.; Zimmermann, A.; Wolf, D.G.; Saleh, N.; Biton, M.; Horwitz, E.; Prokocimer, Z.; Prichard, M.; Hahn, G.; et al. Host immune system gene targeting by a viral miRNA. Science 2007, 317, 376-381. [CrossRef] [PubMed]

308. Wu, J.; Zhang, X.-J.; Shi, K.-Q.; Chen, Y.-P.; Ren, Y.-F.; Song, Y.-J.; Li, G.; Xue, Y.-F.; Fang, Y.-X.; Deng, Z.-J.; et al. Hepatitis B surface antigen inhibits MICA and MICB expression via induction of cellular miRNAs in hepatocellular carcinoma cells. Carcinogenesis 2014, 35, 155-163. [CrossRef] [PubMed]

309. Rasmussen, K.D.; Simmini, S.; Abreu-Goodger, C.; Bartonicek, N.; Di Giacomo, M.; Bilbao-Cortes, D.; Horos, R.; Von Lindern, M.; Enright, A.J.; O'Carroll, D. The miR-144/451 locus is required for erythroid homeostasis. J. Exp. Med. 2010, 207, 1351-1358. [CrossRef] 
310. Sandberg, R.; Neilson, J.R.; Sarma, A.; Sharp, P.A.; Burge, C.B. Proliferating cells express mRNAs with shortened 3'untranslated regions and fewer microRNA target sites. Science 2008, 320, 1643-1647. [CrossRef]

311. Muljo, S.A.; Ansel, K.M.; Kanellopoulou, C.; Livingston, D.M.; Rao, A.; Rajewsky, K. Aberrant T cell differentiation in the absence of Dicer. J. Exp. Med. 2005, 202, 261-269. [CrossRef]

312. Xiao, C.; Srinivasan, L.; Calado, D.P.; Patterson, H.C.; Zhang, B.; Wang, J.; Henderson, J.M.; Kutok, J.L.; Rajewsky, K. Lymphoproliferative disease and autoimmunity in mice with increased miR-17-92 expression in lymphocytes. Nat. Immunol. 2008, 9, 405-414. [CrossRef]

313. Zhou, X.; Jeker, L.T.; Fife, B.T.; Zhu, S.; Anderson, M.S.; McManus, M.T.; Bluestone, J.A. Selective miRNA disruption in T reg cells leads to uncontrolled autoimmunity. J. Exp. Med. 2008, 205, 1983-1991. [CrossRef] [PubMed]

314. Lu, L.-F.; Thai, T.-H.; Calado, D.P.; Chaudhry, A.; Kubo, M.; Tanaka, K.; Loeb, G.B.; Lee, H.; Yoshimura, A.; Rajewsky, K.; et al. Foxp3-dependent microRNA155 confers competitive fitness to regulatory $\mathrm{T}$ cells by targeting SOCS1 protein. Immunity 2009, 30, 80-91. [CrossRef]

315. Du, C.; Liu, C.; Kang, J.; Zhao, G.; Ye, Z.; Huang, S.; Li, Z.; Wu, Z.; Pei, G. MicroRNA miR-326 regulates T H-17 differentiation and is associated with the pathogenesis of multiple sclerosis. Nat. Immunol. 2009, 10, 1252. [CrossRef] [PubMed]

316. Chen, C.-Z.; Li, L.; Lodish, H.F.; Bartel, D.P. MicroRNAs modulate hematopoietic lineage differentiation. Science 2004, 303, 83-86. [CrossRef] [PubMed]

317. Zhou, B.; Wang, S.; Mayr, C.; Bartel, D.P.; Lodish, H.F. MiR-150, a microRNA expressed in mature B and T cells, blocks early B cell development when expressed prematurely. Proc. Natl. Acad. Sci. USA 2007, 104, 7080-7085. [CrossRef] [PubMed]

318. Xiao, C.; Calado, D.P.; Galler, G.; Thai, T.-H.; Patterson, H.C.; Wang, J.; Rajewsky, N.; Bender, T.P.; Rajewsky, K. MiR-150 controls B cell differentiation by targeting the transcription factor c-Myb. Cell 2007, 131, 146-159. [CrossRef]

319. Vigorito, E.; Perks, K.L.; Abreu-Goodger, C.; Bunting, S.; Xiang, Z.; Kohlhaas, S.; Das, P.P.; Miska, E.A.; Rodriguez, A.; Bradley, A.; et al. MicroRNA-155 regulates the generation of immunoglobulin class-switched plasma cells. Immunity 2007, 27,847-859. [CrossRef]

320. Faraoni, I.; Antonetti, F.R.; Cardone, J.; Bonmassar, E. MiR-155 gene: A typical multifunctional microRNA. Biochim. Biophys. Acta BBA Mol. Basis Dis. 2009, 1792, 497-505. [CrossRef]

321. Vigorito, E.; Kohlhaas, S.; Lu, D.; Leyland, R. MiR-155: An ancient regulator of the immune system. Immunol. Rev. 2013, 253, 146-157. [CrossRef]

322. Yang, M.; Shen, H.; Qiu, C.; Ni, Y.; Wang, L.; Dong, W.; Liao, Y.; Du, J. High expression of miR-21 and miR-155 predicts recurrence and unfavourable survival in non-small cell lung cancer. Eur. J. Cancer 2013, 49, 604-615. [CrossRef]

323. Mattiske, S.; Suetani, R.J.; Neilsen, P.M.; Callen, D.F. The oncogenic role of miR-155 in breast cancer. Cancer Epidemiol. Prev. Biomark. 2012, 21, 1236-1243. [CrossRef] [PubMed]

324. Pu, J.; Bai, D.; Yang, X.; Lu, X.; Xu, L.; Lu, J. Adrenaline promotes cell proliferation and increases chemoresistance in colon cancer HT29 cells through induction of miR-155. Biochem. Biophys. Res. Commun. 2012, 428, 210-215. [CrossRef] [PubMed]

325. Kong, X.; Liu, F.; Gao, J. MiR-155 promotes epithelial-mesenchymal transition in hepatocellular carcinoma cells through the activation of PI3K/SGK3/ $\beta$-catenin signaling pathways. Oncotarget 2016, 7, 66051. [CrossRef] [PubMed]

326. Wang, B.; Majumder, S.; Nuovo, G.; Kutay, H.; Volinia, S.; Patel, T.; Schmittgen, T.D.; Croce, C.; Ghoshal, K.; Jacob, S.T. Role of microRNA-155 at early stages of hepatocarcinogenesis induced by choline-deficient and amino acid-defined diet in C57BL/6 mice. Hepatology 2009, 50, 1152-1161. [CrossRef]

327. Chen, Z.; Ma, T.; Huang, C.; Hu, T.; Li, J. The pivotal role of microRNA-155 in the control of cancer. J. Cell. Physiol. 2014, 229, 545-550. [CrossRef]

328. Gui, Y.; Yeganeh, M.; Donates, Y.; Tobelaim, W.; Chababi, W.; Mayhue, M.; Yoshimura, A.; Ramanathan, S.; Saucier, C.; Ilangumaran, S. Regulation of MET receptor tyrosine kinase signaling by suppressor of cytokine signaling 1 in hepatocellular carcinoma. Oncogene 2015, 34, 5718-5728. [CrossRef]

329. Yang, L.; Boldin, M.P.; Yu, Y.; Liu, C.S.; Ea, C.-K.; Ramakrishnan, P.; Taganov, K.D.; Zhao, J.L.; Baltimore, D. MiR-146a controls the resolution of T cell responses in mice. J. Exp. Med. 2012, 209, 1655-1670. [CrossRef] 
330. Wang, P.; Hou, J.; Lin, L.; Wang, C.; Liu, X.; Li, D.; Ma, F.; Wang, Z.; Cao, X. Inducible microRNA-155 feedback promotes type I IFN signaling in antiviral innate immunity by targeting suppressor of cytokine signaling 1. J. Immunol. 2010, 185, 6226-6233. [CrossRef]

331. Sasi, W.; Sharma, A.K.; Mokbel, K. The role of suppressors of cytokine signalling in human neoplasms. Mol. Biol. Int. 2014, 2014, 630797. [CrossRef]

332. Xia, H.B.; Wang, H.J.; Song, S.S.; Zhang, J.G.; He, X.L.; Hu, Z.M.; Zhang, C.W.; Huang, D.S.; Mou, X.Z. Decreased DC-SIGNR expression in hepatocellular carcinoma predicts poor patient prognosis. Oncol. Lett. 2020, 19, 69-76. [CrossRef]

333. Maeda, S. NF-KB, JNK, and TLR signaling pathways in hepatocarcinogenesis. Gastroenterol. Res. Pract. 2010, 2010, 367694. [CrossRef] [PubMed]

334. Yan, J.; Liu, X.-L.; Xiao, G.; Li, N.-L.; Deng, Y.-N.; Han, L.-Z.; Yin, L.-C.; Ling, L.-J.; Liu, L.-X. Prevalence and clinical relevance of T-helper cells, Th17 and Th1, in hepatitis B virus-related hepatocellular carcinoma. PLoS ONE 2014, 9, e96080. [CrossRef] [PubMed]

335. Zhao, H.-Q.; Li, W.-M.; Lu, Z.-Q.; Yao, Y.-M. Roles of Tregs in development of hepatocellular carcinoma: A meta-analysis. World J. Gastroenterol. WJG 2014, 20, 7971. [CrossRef] [PubMed]

336. Stelekati, E.; Chen, Z.; Manne, S.; Kurachi, M.; Ali, M.-A.; Lewy, K.; Cai, Z.; Nzingha, K.; McLane, L.M.; Hope, J.L.; et al. Long-term persistence of exhausted CD8 T cells in chronic infection is regulated by MicroRNA-155. Cell Rep. 2018, 23, 2142-2156. [CrossRef]

337. Hayashita, Y.; Osada, H.; Tatematsu, Y.; Yamada, H.; Yanagisawa, K.; Tomida, S.; Yatabe, Y.; Kawahara, K.; Sekido, Y.; Takahashi, T. A polycistronic microRNA cluster, miR-17-92, is overexpressed in human lung cancers and enhances cell proliferation. Cancer Res. 2005, 65, 9628-9632. [CrossRef]

338. Tsuchida, A.; Ohno, S.; Wu, W.; Borjigin, N.; Fujita, K.; Aoki, T.; Ueda, S.; Takanashi, M.; Kuroda, M. MiR-92 is a key oncogenic component of the miR-17-92 cluster in colon cancer. Cancer Sci. 2011, 102, 2264-2271. [CrossRef]

339. Kim, K.; Chadalapaka, G.; Lee, S.; Yamada, D.; Sastre-Garau, X.; Defossez, P.-A.; Park, Y.-Y.; Lee, J.-S.; Safe, S. Identification of oncogenic microRNA-17-92/ZBTB4/specificity protein axis in breast cancer. Oncogene 2012, 31, 1034-1044. [CrossRef]

340. Zhang, Y.; Zheng, L.; Ding, Y.; Li, Q.; Wang, R.; Liu, T.; Sun, Q.; Yang, H.; Peng, S.; Wang, W.; et al. MiR-20a induces cell radioresistance by activating the PTEN/PI3K/Akt signaling pathway in hepatocellular carcinoma. Int. J. Radiat. Oncol. Biol. Phys. 2015, 92, 1132-1140. [CrossRef]

341. Shan, S.W.; Fang, L.; Shatseva, T.; Rutnam, Z.J.; Yang, X.; Du, W.; Lu, W.-Y.; Xuan, J.W.; Deng, Z.; Yang, B.B. Mature miR-17-5p and passenger miR-17-3p induce hepatocellular carcinoma by targeting PTEN, GalNT7 and vimentin in different signal pathways. J. Cell Sci. 2013, 126, 1517-1530. [CrossRef]

342. Dong-Dong, L.; Xi-Ran, Z.; Xiang-Rong, C. Expression and significance of new tumor suppressor gene PTEN in primary liver cancer. J. Cell. Mol. Med. 2003, 7, 67-71. [CrossRef]

343. Miyagawa, K.; Sakakura, C.; Nakashima, S.; Yoshikawa, T.; Kin, S.; Nakase, Y.; Ito, K.; Yamagishi, H.; Ida, H.; Yazumi, S.; et al. Down-regulation of RUNX1, RUNX3 and CBF $\beta$ in hepatocellular carcinomas in an early stage of hepatocarcinogenesis. Anticancer. Res. 2006, 26, 3633-3643. [PubMed]

344. Liu, C.; Xu, D.; Xue, B.; Liu, B.; Li, J.; Huang, J. Upregulation of RUNX1 suppresses proliferation and migration through repressing VEGFA expression in hepatocellular carcinoma. Pathol. Oncol. Res. 2020, 26, 1301-1311. [CrossRef] [PubMed]

345. Dougherty, G.; Duncan, M.B.; Rohlman, C.E.; Rehman, A.; Thakur, P. The Role of CSF1 in Hepatocellular Carcinoma-Recruited Macrophages; Federation of American Societies for Experimental Biology: Bethesda, MA, USA, 2013.

346. Sasaki, M.; Tsuneyama, K.; Ishikawa, A.; Nakanuma, Y. Intrahepatic cholangiocarcinoma in cirrhosis presents granulocyte and granulocyte-macrophage colony-stimulating factor. Hum. Pathol. 2003, 34, 1337-1344. [CrossRef] [PubMed]

347. Bouillet, P.; O'reilly, L.A. CD95, BIM and T cell homeostasis. Nat. Rev. Immunol. 2009, 9, 514-519. [CrossRef]

348. Sancho, D.; Gómez, M.; Sánchez-Madrid, F. CD69 is an immunoregulatory molecule induced following activation. Trends Immunol. 2005, 26, 136-140. [CrossRef]

349. Koralov, S.B.; Muljo, S.A.; Galler, G.R.; Krek, A.; Chakraborty, T.; Kanellopoulou, C.; Jensen, K.; Cobb, B.S.; Merkenschlager, M.; Rajewsky, N.; et al. Dicer ablation affects antibody diversity and cell survival in the B lymphocyte lineage. Cell 2008, 132, 860-874. [CrossRef] 
350. Taylor, M.A.; Sossey-Alaoui, K.; Thompson, C.L.; Danielpour, D.; Schiemann, W.P. TGF- $\beta$ upregulates miR-181a expression to promote breast cancer metastasis. J. Clin. Investig. 2013, 123, 150-163. [CrossRef]

351. Gao, W.; Yu, Y.; Cao, H.; Shen, H.; Li, X.; Pan, S.; Shu, Y. Deregulated expression of miR-21, miR-143 and miR-181a in non small cell lung cancer is related to clinicopathologic characteristics or patient prognosis. Biomed. Pharmacother. 2010, 64, 399-408. [CrossRef]

352. Han, P.; Li, J.-W.; Zhang, B.-M.; Lv, J.-C.; Li, Y.-M.; Gu, X.-Y.; Yu, Z.-W.; Jia, Y.-H.; Bai, X.-F.; Li, L.; et al. The lncRNA CRNDE promotes colorectal cancer cell proliferation and chemoresistance via miR-181a-5p-mediated regulation of Wnt/ $\beta$-catenin signaling. Mol. Cancer 2017, 16, 9. [CrossRef]

353. Yang, J.; He, Y.; Zhai, N.; Ding, S.; Li, J.; Peng, Z. MicroRNA-181a inhibits autophagy by targeting Atg5 in hepatocellular carcinoma. Front. Biosci. Landmark Ed. 2018, 23, 388-396.

354. Tian, Y.; Xiao, X.; Gong, X.; Peng, F.; Xu, Y.; Jiang, Y.; Gong, G. HBx promotes cell proliferation by disturbing the cross-talk between miR-181a and PTEN. Sci. Rep. 2017, 7, 1-11. [CrossRef]

355. Ji, J.; Yamashita, T.; Wang, X.W. Wnt/beta-catenin signaling activates microRNA-181 expression in hepatocellular carcinoma. Cell Biosci. 2011, 1, 4. [CrossRef] [PubMed]

356. Xie, W.; Li, M.; Xu, N.; Lv, Q.; Huang, N.; He, J.; Zhang, Y. MiR-181a regulates inflammation responses in monocytes and macrophages. PLoS ONE 2013, 8, e58639. [CrossRef]

357. Wu, C.; Gong, Y.; Yuan, J.; Zhang, W.; Zhao, G.; Li, H.; Sun, A.; Zou, Y.; Ge, J. MicroRNA-181a represses ox-LDL-stimulated inflammatory response in dendritic cell by targeting c-Fos. J. Lipid Res. 2012, 53, 2355-2363. [CrossRef] [PubMed]

358. Prieto, J. Inflammation, HCC and sex: IL-6 in the centre of the triangle. J. Hepatol. 2008, 48, 380-381. [CrossRef]

359. Xie, W.; Li, Z.; Li, M.; Xu, N.; Zhang, Y. MiR-181a and inflammation: MiRNA homeostasis response to inflammatory stimuli in vivo. Biochem. Biophys. Res. Commun. 2013, 430, 647-652. [CrossRef] [PubMed]

360. Liu, Y.; Yang, Z.; Du, F.; Yang, Q.; Hou, J.; Yan, X.; Geng, Y.; Zhao, Y.; Wang, H. Molecular mechanisms of pathogenesis in hepatocellular carcinoma revealed by RNA-sequencing. Mol. Med. Rep. 2017, 16, 6674-6682. [CrossRef]

361. Villanueva, A.; Alsinet, C.; Yanger, K.; Hoshida, Y.; Zong, Y.; Toffanin, S.; Rodriguez-Carunchio, L.; Solé, M.; Thung, S.; Stanger, B.Z.; et al. Notch signaling is activated in human hepatocellular carcinoma and induces tumor formation in mice. Gastroenterology 2012, 143, 1660-1669. [CrossRef]

362. Slaby, O.; Svoboda, M.; Fabian, P.; Smerdova, T.; Knoflickova, D.; Bednarikova, M.; Nenutil, R.; Vyzula, R. Altered expression of miR-21, miR-31, miR-143 and miR-145 is related to clinicopathologic features of colorectal cancer. Oncology 2007, 72, 397-402. [CrossRef]

363. Frankel, L.B.; Christoffersen, N.R.; Jacobsen, A.; Lindow, M.; Krogh, A.; Lund, A.H. Programmed cell death 4 (PDCD4) is an important functional target of the microRNA miR-21 in breast cancer cells. J. Biol. Chem. 2008, 283, 1026-1033. [CrossRef]

364. Lu, T.X.; Hartner, J.; Lim, E.-J.; Fabry, V.; Mingler, M.K.; Cole, E.T.; Orkin, S.H.; Aronow, B.J.; Rothenberg, M.E. MicroRNA-21 limits in vivo immune response-mediated activation of the IL-12/IFN- $\gamma$ pathway, Th1 polarization, and the severity of delayed-type hypersensitivity. J. Immunol. 2011, 187, 3362-3373. [CrossRef] [PubMed]

365. Ando, Y.; Yang, G.-X.; Kenny, T.P.; Kawata, K.; Zhang, W.; Huang, W.; Leung, P.S.; Lian, Z.-X.; Okazaki, K.; Ansari, A.A.; et al. Overexpression of microRNA-21 is associated with elevated pro-inflammatory cytokines in dominant-negative TGF- $\beta$ receptor type II mouse. J. Autoimmun. 2013, 41, 111-119. [CrossRef] [PubMed]

366. Tan, M.; Wu, J.; Cai, Y. Suppression of Wnt signaling by the miR-29 family is mediated by demethylation of WIF-1 in non-small-cell lung cancer. Biochem. Biophys. Res. Commun. 2013, 438, 673-679. [CrossRef] [PubMed]

367. Jiang, H.; Zhang, G.; Wu, J.-H.; Jiang, C.-P. Diverse roles of miR-29 in cancer. Oncol. Rep. 2014, 31, $1509-1516$. [CrossRef]

368. Ogata-Kawata, H.; Izumiya, M.; Kurioka, D.; Honma, Y.; Yamada, Y.; Furuta, K.; Gunji, T.; Ohta, H.; Okamoto, H.; Sonoda, H.; et al. Circulating exosomal microRNAs as biomarkers of colon cancer. PLoS ONE 2014, 9, e92921. [CrossRef]

369. Roy, S.; Levi, E.; Majumdar, A.P.; Sarkar, F.H. Expression of miR-34 is lost in colon cancer which can be re-expressed by a novel agent CDF. J. Hematol. Oncol. 2012, 5, 58. [CrossRef] 
370. Kato, M.; Paranjape, T.; Ullrich, R.; Nallur, S.; Gillespie, E.; Keane, K.; Esquela-Kerscher, A.; Weidhaas, J.; Slack, F. The mir-34 microRNA is required for the DNA damage response in vivo in C. elegans and in vitro in human breast cancer cells. Oncogene 2009, 28, 2419-2424. [CrossRef]

371. Stahlhut, C.; Slack, F.J. Combinatorial action of microRNAs let-7 and miR-34 effectively synergizes with erlotinib to suppress non-small cell lung cancer cell proliferation. Cell Cycle 2015, 14, 2171-2180. [CrossRef]

372. Li, G.; Cai, G.; Li, D.; Yin, W. MicroRNAs and liver disease: Viral hepatitis, liver fibrosis and hepatocellular carcinoma. Postgrad. Med. J. 2014, 90, 106-112. [CrossRef]

373. Witwer, K.W. Circulating microRNA biomarker studies: Pitfalls and potential solutions. Clin. Chem. 2015, 61, 56-63. [CrossRef]

374. Cheng, C.J.; Bahal, R.; Babar, I.A.; Pincus, Z.; Barrera, F.; Liu, C.; Svoronos, A.; Braddock, D.T.; Glazer, P.M.; Engelman, D.M.; et al. MicroRNA silencing for cancer therapy targeted to the tumour microenvironment. Nature 2015, 518, 107-110. [CrossRef] [PubMed]

375. Turchinovich, A.; Tonevitsky, A.G.; Burwinkel, B. Extracellular miRNA: A Collision of Two Paradigms. Trends Biochem. Sci. 2016, 41, 883-892. [CrossRef] [PubMed]

376. Turchinovich, A.; Samatov, T.; Tonevitsky, A.; Burwinkel, B. Circulating miRNAs: Cell-cell communication function? Front. Genet. 2013, 4, 119. [CrossRef] [PubMed]

377. Nassar, W.; El-Ansary, M.; Fayyad, T.; Aziz, M.A. Extracellular micro-RNAs in health and disease: Basic science, biogenesis and release. Am. J. Mol. Biol. 2016, 6, 1. [CrossRef]

378. Petrovic, N.; Ergun, S. MiRNAs as potential treatment targets and treatment options in cancer. Mol. Diagn. Ther. 2018, 22, 157-168. [CrossRef]

379. Awasthi, R.; Rathbone, M.J.; Hansbro, P.M.; Bebawy, M.; Dua, K. Therapeutic prospects of microRNAs in cancer treatment through nanotechnology. Drug Deliv. Transl. Res. 2018, 8, 97-110. [CrossRef]

380. Conde, J.; Artzi, N. Are RNAi and miRNA therapeutics truly dead? Trends Biotechnol. 2015, 33, 141-144. [CrossRef]

(C) 2020 by the authors. Licensee MDPI, Basel, Switzerland. This article is an open access article distributed under the terms and conditions of the Creative Commons Attribution (CC BY) license (http://creativecommons.org/licenses/by/4.0/). 